\title{
MONITORING AND EVALUATION OF COASTAL WATER QUALITY PARAMETERS IN FETHIYE BAY, TURKEY
}

\author{
YILDIRIM, P. - BALAS, L.* \\ Sea and Aquatic Sciences Application and Research Center, Gazi University, Ankara, Turkey \\ *Corresponding author \\ e-mail:lalebal@gazi.edu.tr
}

(Received $5^{\text {th }}$ Mar 2019; accepted 20 $0^{\text {th }}$ Aug 2019)

\begin{abstract}
The physical, microbiological quality parameters and plankton abundance have been monitored and evaluated in coastal waters of Fethiye Inner Bay, Turkey. The temporal and areal variations of quality parameters have been investigated through the monthly measurements at 14 locations between March 2016 and February 2017. The physical parameters measured throughout the water column were water temperature, salinity, $\mathrm{pH}$, and turbidity. Besides, water samples were taken from the surface waters, and total coliform, fecal coliform, fecal streptococci, Escherichia coli, Pseudomonas aeruginosa, Salmonella detection, phytoplankton and zooplankton abundance analyses were performed in the laboratory. By using the related Turkish Standards Institution (TSE) standards, biochemical oxygen demand and dissolved oxygen levels were also determined. Results were evaluated to understand the microbiological water quality of Fethiye Inner Bay, by the Turkish Regulations for the Surface Water Quality (2016) and the Quality of Bathing Water (2006), and Directive 2006/7/EC on bathing water. For the evaluation of the results, geographic information systems (GIS) based HYDROTAM-3D that is the first coastal waters hydrodynamic, transport and water quality model developed in Turkey, was used (http://www.hydrotam3d.com/fethiye). A microbiological parameters database was established for Fethiye Inner bay coastal waters by using HYDROTAM-3D model water quality management system, accessible over the internet.
\end{abstract}

Keywords: marine environment, pollution, HYDROTAM-3D, microbiological parameters, phytoplankton, zooplankton, biochemical oxygen demand, dissolved oxygen, Fethiye Bay

\section{Introduction}

People take the water from the hydrological cycle for their vital and economic needs, and the water used returns back to the cycle. In this cycle, substances that enter the water cause the pollution by changing the physical, chemical and biological properties of the water. The main factors that accelerate water pollution are population growth and rapid industrialization (Liyanage and Yamada, 2017). Water is a vital source of infections that can be transmitted through the digestive system. Pathogenic bacteria and other microorganisms mix with water in feces and similar ways depending on many factors such as the geographical location of the region, infrastructure facilities, sewage processes, the socio-economic structure of the community. Viruses, pathogenic bacteria, and parasites can be found in the water as harmful biological agents for human health (Griffin et al., 2003).

The increasing use of water due to population increase and developing industrialization is a crucial factor accelerating water pollution. Pollutants discharged from the point sources such as domestic and industrial sea outfalls or discharged from the distributed sources also pollute the water resources and prevent other uses of receiving waters. Protection of water resources, development, prevention of deterioration in quality and sustainable use of water for long-term conservation of water resources is necessary. 
Fecal coliforms and fecal streptococci are dangerous indicators of health associated with fecal contamination (Barcina et al., 1991). The main entranceway of enteric bacteria and viruses such as Escherichia coli to coastal areas is by urban and agricultural wastes (Rees et al., 2010). Enteric bacteria exposed to the marine environment simultaneously, different to their natural habitat, encounter a variety of abiotic and biotic challenges that is marked (Rozen and Belkin, 2001). Biotic stress arises from natural seawater microbiota, which are better scavengers for limited nutrients available and may also prey and graze on the enteric newcomers. Abiotic stress faced by enteric bacteria in seawater include sunlight temperature, $\mathrm{pH}$, lack of nutrients, salinity, current and turbulence and (possibly) hydrostatic pressure (Troussellier et al., 1998; Barcina et al., 1991; Rozen and Belkin, 2001). Lack of water quality management of coastal waters can lead to both health and income losses at shellfish trade centers and fishing places (Rees et al., 2010). Continuous water quality management at coastal waters are vital for human health. In this study, measurements and evaluations of physical, microbiological quality parameters and plankton abundance were performed for Fethiye Inner Bay. The monthly variations of microbiological quality parameters were investigated through the site measurements conducted in between March 2016 and February 2017.

The Fethiye Bay is located in the Eastern Mediterranean coast of Turkey. It is a sheltered area against currents and waves approaching from north, west and southeast directions. Fethiye Inner Bay is an enclosed water body having limited water exchange from the openings on both sides of the Şövalye (Zeytin) Island located in the Fethiye Bay (Cebe, 2016) and it is surrounded by the town of Fethiye. The primary economic activity in the town is tourism. Besides the tourism, its economy is mainly based on agriculture and animal husbandry (Cebe, 2016). Due to the compatibility of climate and physical conditions, irrigated agriculture is mostly performed in the town. The drainage waters of agricultural lands flow to the waters of Fethiye Bay via Murt (Mersinli) and other channels. Low flushing rate of the enclosed Inner Bay waters increases the sensitivity to pollutants.

The wastewater of the Fethiye Town is transferred to the treatment plant and then discharged to the Inner Bay from the eastern part of the Şövalye (Zeytin) Island (Fig. 1). The treated wastewater is rich in nitrogen and phosphorus, and it has been discharged into Fethiye Inner Bay together with the agricultural drainage waters that are also rich in nitrogen and phosphorus salts carried by the Murt River. The pollution in Murt River alone has a potential to affect the inner bay of Fethiye. Also, seven channels discharge the agricultural drainage waters directly into Fethiye Inner Bay without any treatment or sedimentation (Fig. 2). Likewise, settlements located in the Şövalye (Zeytin) Island and in the west of the bay constitute one of the primary sources of pollution because they are not connected to the wastewater system, and are not subject to the treatment. Other sources of pollution are Fethiye Marina and wastewaters emptied from the boats (Yllmaz et al., 2017). In this study, it is aimed to determine the coastal pollution level in Fethiye Inner Bay, to analyze the temporal and areal changes of water quality parameters and establish a database for evaluations.

\section{Measurements and analysis}

The field study has been conducted monthly between March 2016 and February 2017, in the Fethiye Inner Bay coastal waters in Turkey shown in Figure 2. Fourteen 
(14) measurement points were located at the site, and their names, water depths, and coordinates are listed in Table 1. Measurements of physical parameters were performed at every 2 meters throughout the water column. The total number of measurements at the site is 1164 for the water temperature, salinity, $\mathrm{pH}$, and 168 for the turbidity, each repeated at least three times. Measurement devices used are listed in Table 2.

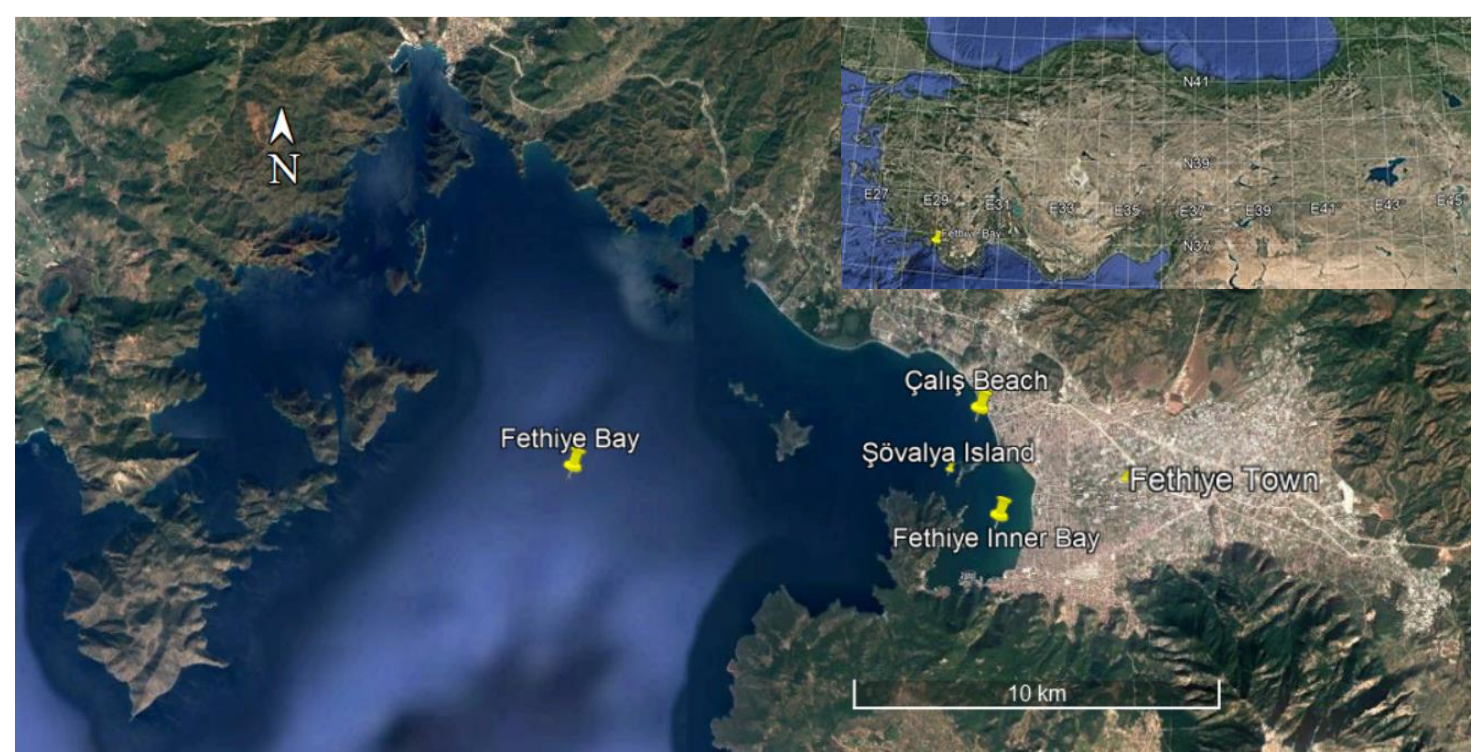

Figure 1. Location of Fethiye Inner Bay and Fethiye Town in Turkey (Google Earth, 2018)

Table 1. Coordinates of the measurement points at the site

\begin{tabular}{c|c|c|c|c|c}
\hline $\begin{array}{c}\text { Point } \\
\text { name }\end{array}$ & $\begin{array}{c}\text { Coordinate } \\
\text { (degree-minute) }\end{array}$ & $\begin{array}{c}\text { Water } \\
\text { depth } \\
\text { (m) }\end{array}$ & $\begin{array}{c}\text { Point } \\
\text { name }\end{array}$ & $\begin{array}{c}\text { Coordinate } \\
\text { (degree-minute) }\end{array}$ & $\begin{array}{c}\text { Water } \\
\text { depth } \\
\text { (m) }\end{array}$ \\
\hline F1 & $36^{\circ} 38.657^{\prime} \mathrm{K}-29^{\circ} 5.787^{\prime} \mathrm{D}$ & 25.3 & $\mathrm{~F} 8$ & $36^{\circ} 38.581^{\prime} \mathrm{K}-29^{\circ} 6.997^{\prime} \mathrm{D}$ & 4.5 \\
F2 & $36^{\circ} 38.384^{\prime} \mathrm{K}-29^{\circ} 5.820^{\prime} \mathrm{D}$ & 17.1 & $\mathrm{~F} 9$ & $36^{\circ} 38.707^{\prime} \mathrm{K}-29^{\circ} 6.499^{\prime} \mathrm{D}$ & 15.4 \\
F3 & $36^{\circ} 38.176^{\prime} \mathrm{K}-29^{\circ} 6.120^{\prime} \mathrm{D}$ & 15.4 & $\mathrm{~F} 10$ & $36^{\circ} 38.944^{\prime} \mathrm{K}-29^{\circ} 6.266^{\prime} \mathrm{D}$ & 16.2 \\
F4 & $36^{\circ} 37.448^{\prime} \mathrm{K}-29^{\circ} 5.690^{\prime} \mathrm{D}$ & 14.7 & $\mathrm{~F} 11$ & $36^{\circ} 38.905^{\prime} \mathrm{K}-29^{\circ} 6.843^{\prime} \mathrm{D}$ & 4.6 \\
F5 & $36^{\circ} 37.680^{\prime} \mathrm{K}-29^{\circ} 6.153^{\prime} \mathrm{D}$ & 15.3 & $\mathrm{~F} 12$ & $36^{\circ} 39.184^{\prime} \mathrm{K}-29^{\circ} 6.528^{\prime} \mathrm{D}$ & 16.3 \\
F6 & $36^{\circ} 38.057^{\prime} \mathrm{K}-29^{\circ} 7.076^{\prime} \mathrm{D}$ & 5.3 & $\mathrm{~F} 13$ & $36^{\circ} 39.666^{\prime} \mathrm{K}-29^{\circ} 6.367^{\prime} \mathrm{D}$ & 15.2 \\
F7 & $36^{\circ} 38.270^{\prime} \mathrm{K}-29^{\circ} 6.621^{\prime} \mathrm{D}$ & 15.2 & $\mathrm{~F} 14$ & $36^{\circ} 39.098^{\prime} \mathrm{K}-29^{\circ} 5.060^{\prime} \mathrm{D}$ & 46 \\
\hline
\end{tabular}

Table 2. Measurement devices

\begin{tabular}{c|c|c}
\hline Measurement device & Measurement & Sensitivity range \\
\hline \multirow{4}{*}{$\begin{array}{c}\text { YSI Pro Plus Model Quatro } \\
(20 \mathrm{~m} \text { cable) }\end{array}$} & $\mathrm{pH}(\mathrm{mV}, \mathrm{pH})$ & \pm 0.2 \\
\cline { 2 - 3 } & Temperature $\left({ }^{\circ} \mathrm{C},{ }^{\circ} \mathrm{F}, \mathrm{K}\right)$ & $\pm 0.2{ }^{\circ} \mathrm{C}$ \\
\cline { 2 - 3 } & Salinity $(\mathrm{ppt}, \mathrm{psu})$ & $\pm 1.0 \% ; \pm 0.1 \mathrm{ppt}$ \\
\cline { 2 - 3 } & $\mathrm{DO}(\mathrm{mg} / \mathrm{L}, \mathrm{ppm})\left(-5\right.$ to $\left.50{ }^{\circ} \mathrm{C}\right)$ & $\begin{array}{c}0 \text { to } 20 \mathrm{mg} / \mathrm{L} \pm 2 \% \\
20-50 \mathrm{mg} / \mathrm{L} ; \pm 6 \%\end{array}$ \\
\hline $\begin{array}{c}\text { HF MicroTPI field portable } \\
\text { turbidimeter }\end{array}$ & $\begin{array}{c}\text { Turbidity } \\
(0.01-1100 \mathrm{ntu} / \mathrm{ftu})\end{array}$ & $\begin{array}{c} \pm 2 \% \text { of reading or } 0.01 \mathrm{ntu}(0-500 \mathrm{ntu}) \\
\pm 3 \% \text { of reading }(500-1100 \mathrm{ntu})\end{array}$ \\
\hline
\end{tabular}




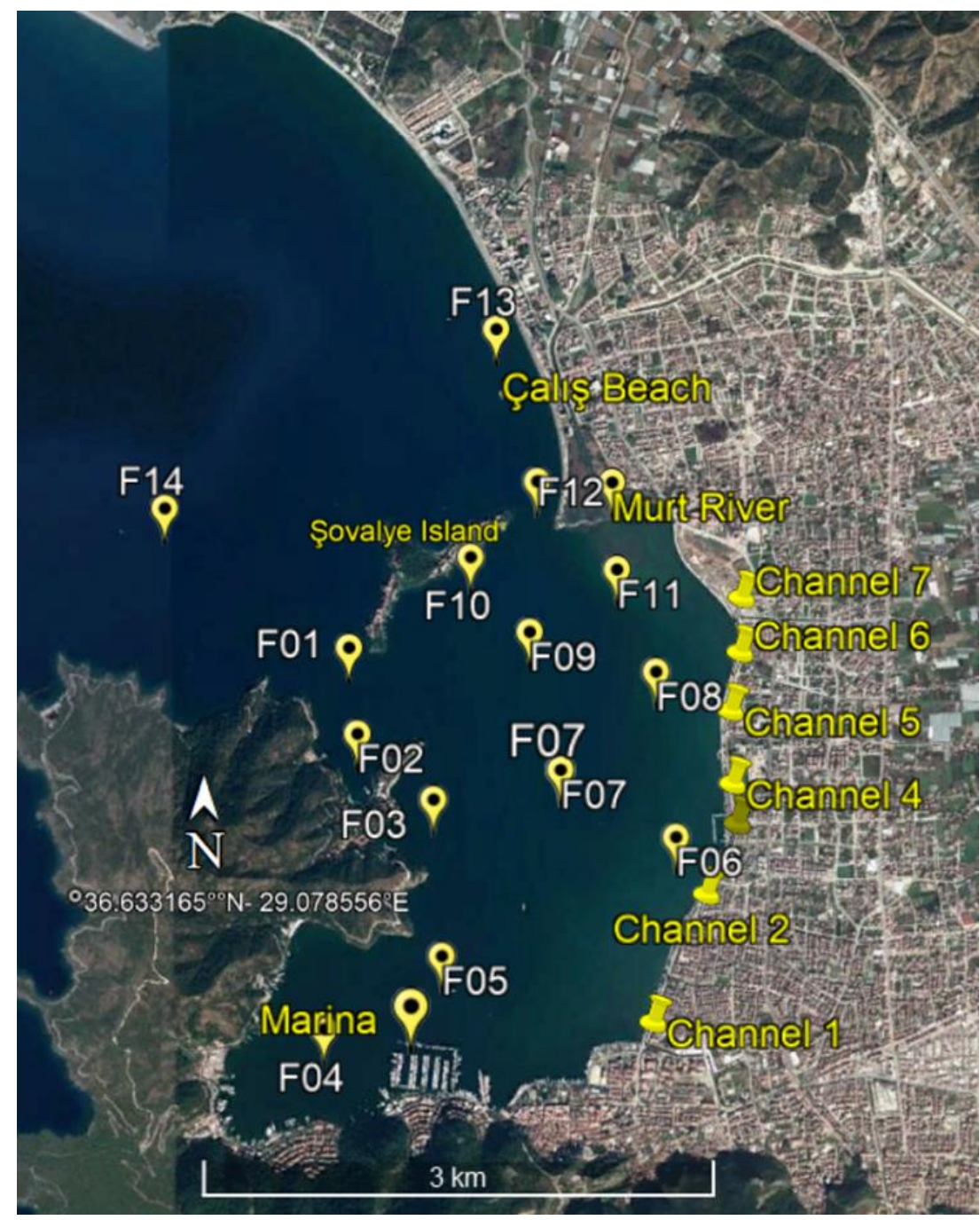

Figure 2. Fethiye Inner Bay measurement points (Google Earth, 2018)

Total coliform, fecal coliform, fecal streptococci, Escherichia coli, Pseudomonas aeruginosa, and Salmonella analysis have been performed in 168 water samples taken for the temporal and spatial analysis of the changes of the bacteriological water quality parameters in the coastal waters. Phytoplankton and zooplankton abundance analyzes have been carried out in the laboratory for water samples taken from the surface and the bottom layer at depths exceeding $8 \mathrm{~m}$ using plankton nets. Biochemical Oxygen Demand (BOD) and Dissolved Oxygen (DO) requirements were determined by the relevant Turkish Standards Institution (TSE) standards for comparison with the changes in bacteriological parameters.

Microbiological laboratory test-methods are given in Table 3 (TS EN ISO 9308-1, 2014; TS EN ISO 16266, 2009; TS EN ISO 7899-2, 2000), BOD and DO test-methods are listed in Table 4 (TS EN ISO 5814, 2012; TS EN ISO 10707, 2005). BOD and DO were detected in 168 and 1164 samples, respectively.

55-micron Hydro-Bios plankton nets were used through the water column vertically to collect phytoplankton and zooplankton samples during the study. Then, both phytoplankton and zooplankton samples were fixed with $4 \%$ formaldehyde buffer solution until counting and identification activities. 
Table 3. Microbiological test-methods

\begin{tabular}{c|c}
\hline Microbiological analysis & Used standards \\
\hline $\begin{array}{c}\text { Enumeration of coliform } \\
\text { bacteria }\end{array}$ & $\begin{array}{c}\text { TS EN ISO 9308-1 Water quality- Detection and enumeration of } \\
\text { Escherichia coli and coliform bacteria Part-1 Membrane filtration method }\end{array}$ \\
\hline Enumeration of & TS EN ISO 9308-1 Water quality- Detection and enumeration of \\
Escherichia coli & Escherichia coli and coliform bacteria Part-1 Membrane filtration method \\
\hline Enumeration of & TS EN ISO 16266 Water quality - Detection and enumeration of \\
Pseudomonas aeruginosa & Pseudomonas aeruginosa -- Method by membrane filtration \\
\hline $\begin{array}{c}\text { Enumeration of intestinal } \\
\text { enterococci }\end{array}$ & $\begin{array}{c}\text { TS EN ISO 7899-2 Water quality - Detection and enumeration of intestinal } \\
\text { enterococci - Part 2: Membrane filtration method }\end{array}$ \\
\hline
\end{tabular}

Table 4. Chemical test-methods

\begin{tabular}{|c|c|}
\hline Chemical analysis & Used standards \\
\hline DO & $\begin{array}{c}\text { TS EN ISO } 5814 \text { Water quality-determination of dissolved oxygen } \\
\text { electrochemical probe method }\end{array}$ \\
\hline BOD & $\begin{array}{l}\text { TS EN ISO } 10707 \text { Water quality - Evaluation in an aqueous medium of the } \\
\text { "ultimate" aerobic biodegradability of organic compounds - Method by } \\
\text { analysis of biochemical oxygen demand (closed bottle test) }\end{array}$ \\
\hline
\end{tabular}

APHA Standard Methods (1995) were used during the counting of phytoplankton and zooplankton samples with Leica DM500 binocular microscope, and SedgewickRafter Counting Chamber was employed as the counting chamber unit. The Sedgewick Rafter Counting Cells are designed primarily for the quantitative measurement of the exact number of particles in a precise volume of a fluid. This chamber itself is $50 \mathrm{~mm}$ in length, $20 \mathrm{~mm}$ in width and $1 \mathrm{~mm}$ in depth. The base part of the chamber is also grid marked with $100 \mathrm{x} 1 \mathrm{~mm}$ squares. Before transferring to the counting chamber, each sample was shaken at least $1 \mathrm{~min}$, and $1 \mathrm{ml}$ of sample were placed in the chamber. During the counting and identification, the number phytoplankton and zooplankton on each counting cell were recorded under the light microscope. Countings were repeated on 8 subsamples (Harris et al., 2000).

\section{Physical parameters}

Physical parameters were measured every $2 \mathrm{~m}$ from the surface to the bottom at each of the 14 stations. Salinity and temperature recorded at all measurement points are given in Figure 3. As a result of 12-month measurements carried out between March 2016 and February 2017, it was observed that the seawater salinity in Fethiye Inner Bay changed between $30.37 \mathrm{ppt}$ (at F06) and $39.43 \mathrm{ppt}$ (at F14) at the surface and the lowest salinity value was recorded in September, and the highest value was recorded in August. The salinity of surface waters is lower in all seasons than in the bottom layers. Towards the sea bottom from the surface, the average salinity increase is $4.35 \mathrm{ppt}$ in the spring, 1.49 ppt in summer, $2.89 \mathrm{ppt}$ in autumn, and $2.85 \mathrm{ppt}$ in winter. Similarly, seawater temperatures were ranging in between 12.7 and $30.8^{\circ} \mathrm{C}$. The seasonal temperature averages decreased from the surface to the bottom of the water column from 20.7 to $18.6^{\circ} \mathrm{C}$ in the spring, from 29.2 to $25.1^{\circ} \mathrm{C}$ in summer, and they remained almost unchanged along the water column with a slight increase from 22.5 to $22.8^{\circ} \mathrm{C}$ in the autumn and 16.8 to $16.8{ }^{\circ} \mathrm{C}$ in winter. Measured $\mathrm{pH}$ values ranged from 7.55 to 8.38 . 
The surface layer $\mathrm{pH}$ and turbidities measured at all points are given in Figure 4. Turbidity recorded at point F14 (water depth is $46 \mathrm{~m}$.) changed in between 0.54 and 3.2 $\mathrm{ntu}$, whereas at all other points ranged in between 1.02 and $4.81 \mathrm{ntu}$. The lowest values were recorded in autumn. All turbidity values were less than $5 \mathrm{ntu}$ that is the acceptable limit for recreational purposes in coastal waters.

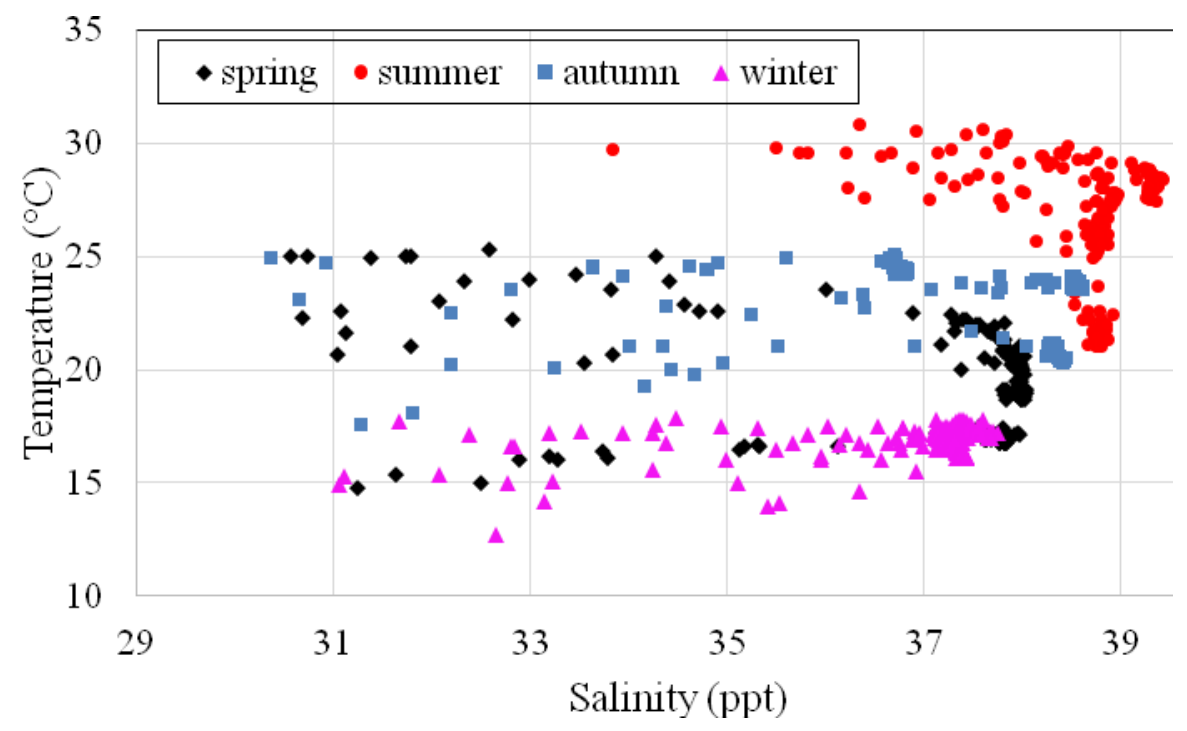

Figure 3. Salinity and temperature recorded at all measurement points

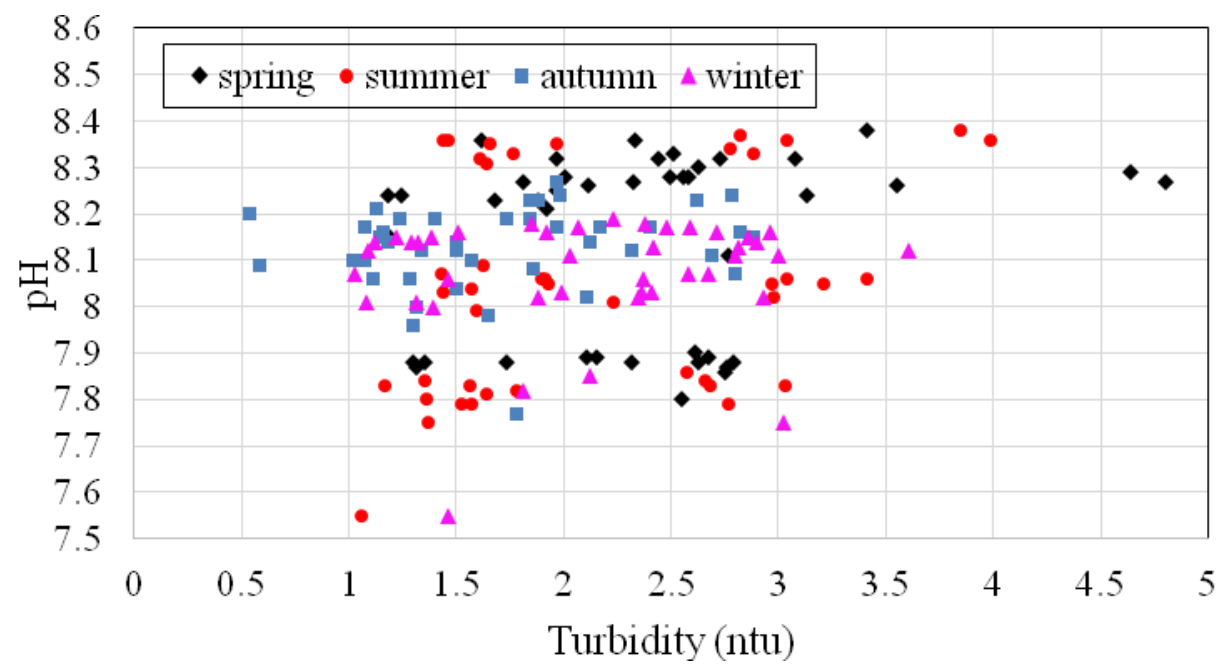

Figure 4. Surface turbidity $(\mathrm{ntu})$ and $\mathrm{pH}$ recorded at all measurement points

\section{Microbiological parameters}

Coliform bacteria are bacteria that show the contamination of coastal waters. These bacteria are found in soil and plants as well as in the feces of warm-blooded animals. Such bacteria are fast-breeding species, and their presence indicates that disease-causing organisms (pathogens) from the feces of humans or animals could be existent in the coastal waters. Coliform bacteria are grouped as total coliform or fecal coliform 
according to general characteristics. Total coliforms (TC) are common in soil or vegetation and do not show that water is contaminated by feces (Gao et al., 2015).

According to the 12-month measurements made between March 2016 and February 2017, the temporal changes in total coliform values at all measurement points are given in Table 5.

Table 5. Temporal variations in TC $(c f u / 100 \mathrm{ml})$ at all measurement points

\begin{tabular}{c|c|c|c|c|c|c|c|c|c|c|c|c|c|c|c}
\hline \multicolumn{2}{l|}{} & F01 & F02 & F03 & F04 & F05 & F06 & F07 & F08 & F09 & F10 & F11 & F12 & F13 & F14 \\
\hline \multirow{6}{*}{2016} & Mar & 57 & 300 & 30 & 55 & 200 & 300 & 230 & 102 & 30 & 45 & 650 & 120 & 48 & 46 \\
& Apr & 414 & 704 & 40 & 160 & 100 & 60 & 240 & 60 & 60 & 40 & 840 & 180 & 160 & 240 \\
& May & 1050 & 600 & 130 & 170 & 430 & 360 & 100 & 40 & 40 & 60 & 900 & 850 & 648 & 260 \\
& Jun & 300 & 100 & 100 & 120 & 40 & 60 & 20 & 120 & 180 & 40 & 50 & 12 & 13 & 10 \\
& Jul & 50 & 50 & 30 & 30 & 20 & 22 & 12 & 30 & 60 & 120 & 1040 & 180 & 20 & 0 \\
& Aug & 410 & 525 & 40 & 100 & 60 & 43 & 70 & 1040 & 70 & 30 & 140 & 120 & 15 & 6090 \\
& Sep & 779 & 413 & 50 & 20 & 20 & 320 & 70 & 40 & 220 & 170 & 450 & 254 & 140 & 0 \\
& Oct & 650 & 0 & 0 & 420 & 20 & 0 & 10 & 0 & 0 & 0 & 0 & 1440 & 0 & 1680 \\
& Nov & 1160 & 2 & 10 & 26 & 130 & 100 & 520 & 50 & 130 & 120 & 26 & 3650 & 460 & 100 \\
& Dec & 650 & 4 & 43 & 52 & 128 & 58 & 378 & 60 & 192 & 417 & 30 & 2850 & 682 & 192 \\
\hline \multirow{6}{*}{2017} & Jan & 90 & 7 & 70 & 80 & 150 & 50 & 240 & 280 & 250 & 750 & 400 & 2150 & 900 & 390 \\
& Feb & 140 & 170 & 0 & 0 & 420 & 600 & 260 & 130 & 0 & 50 & 0 & 200 & 50 & 140 \\
\hline
\end{tabular}

Measured coliform bacteria values provide guidance value $(500 \mathrm{cfu} / 100 \mathrm{ml})$ of the Quality Criteria Table to be provided by Bathing Water Quality for Swimming and Recreation purposes, Annex-1 of Regulation for the Quality of Bathing Water (2006). The $15.5 \%$ of samples were above the guide standard however they were all less than the mandatory standard $(10000 \mathrm{cfu} / 100 \mathrm{ml})$. In $91.7 \%$ of the samples TC was recorded. According to measured values, it is seen that the total coliform bacteria density is low in Fethiye Inner Bay coastal waters. However, coliform contamination was found at the mouth of Murt River (F11), along with the Çalış Beach (F12, F13), and in holiday village swimming bay (F01, F02) during the rainy spring and winter months. While this pollution is lower than the mandatory standard, its presence suggests that there may also be pathogens from the feces of humans or animals in the water.

Coliform bacteria originate as organisms in soil or vegetation and the intestinal tract of warm-blooded animals (fecal coliform). Fecal coliform (FC) bacteria are indicators of fecal contamination and the potential presence of pathogens associated with wastewater or sewage sludge. The total group includes FC bacteria such as Escherichia coli, as well as other types of coliform bacteria that are naturally found in the soil. The presence of fecal coliform in water may indicate recent contamination of the water by sewage or feces which could contain other bacteria, viruses, or disease-causing organisms. This is why coliform bacteria are considered "indicator organisms"; their presence warns of the potential presence of disease-causing organisms and should alert the person responsible for the water to take precautionary action (Gao et al., 2015).

The temporal variations in fecal coliform values at all measurement points according to the 12-month measurements made between March 2016 and February 2017 are shown in Table 6. 
Table 6. Temporal variations in FC (cfu/l00 ml) at all measurement points

\begin{tabular}{c|c|c|c|c|c|c|c|c|c|c|c|c|c|c|c}
\hline \multicolumn{1}{l}{} & & F01 & F02 & F03 & F04 & F05 & F06 & F07 & F08 & F09 & F10 & F11 & F12 & F13 & F14 \\
\hline \multirow{6}{*}{2016} & Mar & 15 & 100 & 5 & 32 & 15 & 200 & 18 & 55 & 18 & 12 & 211 & 60 & 34 & 33 \\
& Apr & 252 & 448 & 20 & 160 & 20 & 60 & 60 & 60 & 40 & 20 & 380 & 100 & 60 & 20 \\
& May & 150 & 130 & 20 & 50 & 50 & 60 & 20 & 30 & 40 & 20 & 900 & 850 & 136 & 170 \\
& Jun & 200 & 80 & 20 & 110 & 20 & 20 & 50 & 40 & 160 & 20 & 12 & 12 & 13 & 0 \\
& Jul & 50 & 58 & 43 & 30 & 24 & 18 & 12 & 10 & 15 & 20 & 220 & 50 & 100 & 0 \\
& Aug & 130 & 147 & 110 & 40 & 32 & 10 & 70 & 1040 & 30 & 5 & 20 & 100 & 10 & 6090 \\
& Sep & 201 & 82 & 54 & 32 & 20 & 120 & 10 & 10 & 220 & 100 & 50 & 166 & 40 & 0 \\
& Oct & 130 & 0 & 0 & 150 & 10 & 0 & 10 & 0 & 0 & 0 & 0 & 360 & 0 & 1680 \\
& Nov & 60 & 1 & 0 & 0 & 50 & 40 & 28 & 1 & 5 & 12 & 22 & 1120 & 30 & 4 \\
& Dec & 22 & 0 & 23 & 28 & 28 & 23 & 22 & 0 & 23 & 13 & 2 & 760 & 82 & 11 \\
\hline \multirow{2}{*}{2017} & Jan & 20 & 30 & 500 & 150 & 5 & 9 & 20 & 50 & 40 & 14 & 8 & 460 & 150 & 19 \\
& Feb & 0 & 0 & 0 & 0 & 128 & 10 & 40 & 0 & 0 & 0 & 0 & 40 & 0 & 20 \\
\hline
\end{tabular}

Measured FC bacteria values satisfy the guide standard $(100 \mathrm{cfu} / 100 \mathrm{ml})$ of the Regulation for the Quality of Bathing Water (2006), Annex-1: Quality Criteria Required for Swimming and Recreation Waters, only at F07 in all of the measurements. In $85.7 \%$ of the samples FC was recorded. The $21.4 \%$ of samples were above the guide standard. At F14, the FC count was almost three times higher than the mandatory level (2000 $\mathrm{cfu} / 100 \mathrm{ml}$ ) in August. Measurements indicate that there is substantial fecal pollution in Fethiye Inner Bay coastal waters. The source might be wastewater, sludge, septage, or animal excreta, resulted from the intensive anthropogenic facilities.

Escherichia coli is a member of the fecal coliform group and a more specific indicator of fecal pollution and commonly used to identify the presence of pathogenic microorganisms (Feng et al., 2012). It can be found in the digestive system of humans and warm-blooded animals. They cause digestive system infection. It is most commonly transmitted to humans by swimming in or swallowing the polluted water. Its presence in seawater indicates the entrance of sewage (Craig et al., 2004). There is a strong correlation between the increased $E$. coli levels in recreational waters, and the gastrointestinal disease even though the vast majority of them are not pathogenic (Blaustein et al., 2013). The temporal variations in E. coli values at all measurement points according to the 12-month measurements made between March 2016 and February 2017 are given in Table 7.

No limit value is defined for E. coli in the Regulation for the Quality of Bathing Water (2006). According to the bathing water quality standards for coastal and transitional waters in Directive 2006/7/EC of The European Parliament and the Council, Annex I, excellent quality and sufficient values of E. coli are stated as 250 and 500 cfu/100 ml, respectively. Similarly, in "Standard Values Required for Coastal and Transitional Waters Used for Recreational Use" (Regulation for the Surface Water Quality, 2016, Annex-5, Table 6) provides a guide standard of $250 \mathrm{cfu} / 100 \mathrm{ml}$ and the mandatory standard of $500 \mathrm{cfu} / 100 \mathrm{ml}$. Measurements indicate that in rainy spring and autumn, E. coli significantly increases. Along the beach (Çalış Beach, F12 and F13 Points), E. coli values have doubled to the mandatory standard. In $38.1 \%$ of the samples E. coli was recorded. The $3.6 \%$ and $1.8 \%$ of samples were above the guide standard and the mandatory standard, respectively. 
Table 7. Temporal variations in E. coli $(c f u / 100 \mathrm{ml})$ at all measurement points

\begin{tabular}{c|c|c|c|c|c|c|c|c|c|c|c|c|c|c|c}
\hline \multicolumn{1}{l}{} & & F01 & F02 & F03 & F04 & F05 & F06 & F07 & F08 & F09 & F10 & F11 & F12 & F13 & F14 \\
\hline \multirow{6}{*}{2016} & Mar & 0 & 0 & 0 & 0 & 0 & 0 & 8 & 0 & 0 & 0 & 42 & 22 & 0 & 0 \\
& Apr & 224 & 392 & 0 & 0 & 20 & 40 & 40 & 40 & 20 & 20 & 63 & 40 & 60 & 0 \\
& May & 0 & 0 & 0 & 0 & 0 & 40 & 0 & 0 & 0 & 0 & 51 & 94 & 850 & 119 \\
& Jun & 0 & 0 & 0 & 0 & 0 & 0 & 0 & 0 & 0 & 0 & 0 & 0 & 0 & 0 \\
& Jul & 0 & 0 & 0 & 0 & 0 & 0 & 0 & 0 & 0 & 0 & 0 & 0 & 2 & 0 \\
& Aug & 87 & 147 & 0 & 0 & 0 & 0 & 10 & 0 & 0 & 0 & 0 & 0 & 0 & 0 \\
& Sep & 201 & 0 & 0 & 0 & 0 & 0 & 0 & 0 & 110 & 0 & 0 & 71 & 20 & 0 \\
& Oct & 43 & 0 & 0 & 0 & 0 & 0 & 0 & 0 & 0 & 0 & 0 & 0 & 0 & 0 \\
& Nov & 36 & 1 & 0 & 0 & 38 & 40 & 28 & 1 & 2 & 0 & 20 & 933 & 25 & 2 \\
& Dec & 5 & 0 & 13 & 12 & 22 & 6 & 18 & 0 & 20 & 7 & 16 & 678 & 43 & 9 \\
\hline \multirow{2}{*}{2017} & Jan & 0 & 0 & 500 & 150 & 5 & 9 & 10 & 0 & 40 & 14 & 8 & 460 & 75 & 19 \\
& Feb & 0 & 0 & 0 & 0 & 0 & 0 & 13 & 0 & 0 & 0 & 0 & 0 & 0 & 10 \\
\hline
\end{tabular}

Fecal streptococci (FS) are also known as enterococci and of intestinal origin. They are a more resistant group of bacteria to be used as fecal pollutant indicators (Sinton et al., 1993). Especially they live in sea waters longer. The temporal variations in FS at all measurement points according to the 12-month measurements made between March 2016 and February 2017 are presented in Table 8.

Table 8. Temporal variations in FS (cfu/l00 ml) at all measurement points

\begin{tabular}{c|c|c|c|c|c|c|c|c|c|c|c|c|c|c|c}
\hline \multicolumn{1}{l}{} & & F01 & F02 & F03 & F04 & F05 & F06 & F07 & F08 & F09 & F10 & F11 & F12 & F13 & F14 \\
\hline \multirow{6}{*}{2016} & Mar & 12 & 39 & 0 & 0 & 0 & 0 & 0 & 1 & 0 & 2 & 12 & 2 & 10 & 3 \\
& Apr & 69 & 137 & 0 & 1 & 0 & 1 & 15 & 2 & 1 & 5 & 235 & 3 & 11 & 39 \\
& May & 16 & 6 & 0 & 5 & 59 & 4 & 3 & 2 & 0 & 0 & 800 & 147 & 40 & 3 \\
& Jun & 0 & 0 & 0 & 0 & 1 & 0 & 0 & 0 & 1 & 0 & 2 & 1 & 1 & 0 \\
& Jul & 0 & 0 & 0 & 0 & 1 & 0 & 0 & 0 & 1 & 0 & 2 & 1 & 1 & 0 \\
& Aug & 27 & 86 & 0 & 1 & 0 & 0 & 0 & 0 & 1 & 0 & 4 & 1 & 3 & 1 \\
& Sep & 82 & 23 & 0 & 0 & 0 & 0 & 0 & 1 & 5 & 17 & 105 & 56 & 28 & 2 \\
& Oct & 25 & 9 & 0 & 0 & 0 & 1 & 9 & 2 & 4 & 34 & 11 & 17 & 4 & 0 \\
& Nov & 11 & 21 & 5 & 0 & 2 & 2 & 11 & 9 & 5 & 13 & 15 & 18 & 16 & 0 \\
& Dec & 8 & 11 & 35 & 60 & 16 & 47 & 17 & 83 & 102 & 14 & 52 & 65 & 228 & 18 \\
\hline \multirow{2}{*}{2017} & Jan & 10 & 0 & 63 & 125 & 25 & 95 & 24 & 155 & 205 & 14 & 100 & 115 & 469 & 38 \\
& Feb & 0 & 12 & 0 & 0 & 10 & 0 & 0 & 0 & 0 & 0 & 0 & 20 & 10 & 0 \\
\hline
\end{tabular}

Measured FS values at F01, F03, F05, F06, F07, F10, and F14, all satisfy the guide standard (100 cfu/100 ml) of the Regulation for the Quality of Bathing Water (2006), Annex-1: Table of Quality Criteria Required for Swimming and Recreation Waters. However, they exceed the guide standard at F02 in April, at F04 and F08 in January, at F09 and F13 in December and January, at F11 in April, May, September, and January, at F12 in May and January. All the measured values are less than the mandatory standard $(1000 \mathrm{cfu} / 100 \mathrm{ml})$. In $66.1 \%$ of the samples FS was recorded. The $7.7 \%$ samples were above the guide standard. 
Microbial degradation of waters used for drinking, irrigation or recreational purposes is monitored using concentration levels of fecal indicator bacteria (the United States Environmental Protection Agency, 2002). However, other bacteria, including gramnegative opportunistic pathogens of humans, Pseudomonas aeruginosa, and HPC bacteria, may also be useful in characterizing the quality of seawater (Carter et al., 2000). P. aeruginosa especially exists in coastal and transitional waters that interact with land (Kimata et al., 2004; Mena and Gerba, 2009). The increase in indicator bacteria in seawater and sediment has been associated with the risk of pathogenic microorganism-induced disease in humans (Donovan et al., 2008). Gastrointestinal diseases, skin infections, and risk of acute respiratory tract infections are increasing in people exposed through the recreational use of coastal waters intensified by indicator bacteria (Karbasdehi et al., 2017). Although not yet in Turkey, many regulations define measures to control $P$. aeruginosa pollution in recreational waters foreseeing such risks (Centers for Diseases Control and Prevention, 2014). The temporal variations in $P$. aeruginosa values at all measurement points according to the 12-month measurements made between March 2016 and February 2017 are summarized in Table 9.

Table 9. Temporal variations in P. aeruginosa $(c f u / 100 \mathrm{ml})$ at all measurement points

\begin{tabular}{|c|c|c|c|c|c|c|c|c|c|c|c|c|c|c|c|}
\hline & & F01 & F02 & F03 & F04 & F05 & F06 & F07 & F08 & F09 & F10 & F11 & F12 & F13 & F14 \\
\hline \multirow{10}{*}{2016} & Mar & 163 & 4 & 2 & 2 & 4 & 89 & 120 & 56 & 52 & 11 & 78 & 825 & 93 & 163 \\
\hline & Apr & 223 & 242 & 8 & 4 & 9 & 13 & 10 & 5 & 2 & 1 & 18 & 77 & 23 & 172 \\
\hline & May & 9 & 13 & 3 & 19 & 84 & 20 & 10 & 0 & 0 & 0 & 0 & 9 & 106 & 9 \\
\hline & Jun & 0 & 0 & 16 & 1 & 1 & 0 & 0 & 0 & 0 & 0 & 0 & 2 & 7 & 0 \\
\hline & Jul & 0 & 0 & 30 & 0 & 12 & 0 & 5 & 0 & 0 & 89 & 0 & 240 & 200 & 123 \\
\hline & Aug & 336 & 1500 & 0 & 0 & 0 & 0 & 0 & 21 & 40 & 60 & 71 & 250 & 200 & 150 \\
\hline & Sep & 920 & 800 & 0 & 0 & 0 & 0 & 0 & 16 & 25 & 40 & 500 & 230 & 35 & 0 \\
\hline & Oct & 60 & 0 & 0 & 0 & 1 & 4 & 10 & 6 & 10 & 122 & 29 & 40 & 3 & 2 \\
\hline & Nov & 320 & 60 & 50 & 0 & 0 & 16 & 0 & 10 & 70 & 0 & 30 & 1520 & 184 & 2 \\
\hline & Dec & 210 & 20 & 221 & 115 & 123 & 348 & 45 & 33 & 56 & 145 & 138 & 2400 & 520 & 45 \\
\hline \multirow{2}{*}{2017} & Jan & 0 & 0 & 410 & 250 & 270 & 720 & 90 & 60 & 40 & 320 & 285 & 3350 & 870 & 80 \\
\hline & Feb & 270 & 920 & 240 & 80 & 820 & 1150 & 740 & 300 & 100 & 20 & 120 & 1750 & 100 & 240 \\
\hline
\end{tabular}

The highest values of $P$. aeruginosa as a pathogenic bacteria was measured at F12 in winter time. No limit value is defined in the regulations for this bacteria in coastal waters. In Italian regulations, it is defined as $1 \mathrm{cfu} / 100 \mathrm{ml}$ (Guida et al., 2016) in swimming pool waters. $P$. aeruginosa was detected as well in the absence of the TC, FC and FS. In $76.2 \%$ of the samples $P$. aeruginosa was recorded.

Salmonella is a pathogenic bacterial species, and it is dangerous for human health. They may enter to coastal waters by land-based anthropological sources, wastewaters, surface flows and ballast waters of marine vessels (Altuğ, 2012). The temporal variations in Salmonella values at all measurement points according to the 12-month measurements made between March 2016 and February 2017 are given in Table 10.

Measured Salmonella values are generally at high levels. They exceed the limit value $(0 \mathrm{cfu} / 100 \mathrm{ml})$ of the Regulation for the Quality of Bathing Water (2006), Annex-1: Table of Quality Criteria Required for Swimming and Recreation Waters. The highest values have been reached at F11, F14 and F02 in August. Salmonella was detected as 
well in the absence of the TC, FC and FS. In 93\% of the samples Salmonella was recorded.

Table 10. Temporal variations in Salmonella $(c f u / 100 \mathrm{ml})$ values at all measurement points

\begin{tabular}{c|c|c|c|c|c|c|c|c|c|c|c|c|c|c|c}
\hline \multicolumn{2}{l|}{} & F01 & F02 & F03 & F04 & F05 & F06 & F07 & F08 & F09 & F10 & F11 & F12 & F13 & F14 \\
\hline \multirow{6}{*}{2016} & Mar & 18 & 22 & 42 & 0 & 12 & 82 & 8 & 15 & 6 & 0 & 3 & 52 & 14 & 9 \\
& Apr & 12 & 180 & 26 & 12 & 3 & 98 & 320 & 280 & 850 & 25 & 5 & 28 & 26 & 125 \\
& May & 150 & 340 & 0 & 0 & 0 & 240 & 700 & 700 & 800 & 0 & 0 & 460 & 100 & 530 \\
& Jun & 410 & 1230 & 1780 & 820 & 700 & 2560 & 450 & 660 & 640 & 9580 & 2650 & 1750 & 2310 & 200 \\
& Jul & 128 & 37 & 58 & 146 & 437 & 56 & 22 & 48 & 23 & 33 & 35 & 487 & 126 & 95 \\
& Aug & 4050 & 10800 & 250 & 1450 & 650 & 5150 & 580 & 2400 & 1240 & 3260 & 18550 & 600 & 5250 & 17500 \\
& Sep & 6350 & 3450 & 350 & 100 & 150 & 300 & 40 & 850 & 900 & 650 & 2650 & 550 & 300 & 100 \\
& Oct & 0 & 5500 & 2600 & 400 & 150 & 550 & 600 & 350 & 150 & 500 & 350 & 0 & 500 & 0 \\
& Nov & 1560 & 900 & 100 & 300 & 980 & 2200 & 2260 & 740 & 860 & 200 & 540 & 2210 & 500 & 720 \\
& Dec & 654 & 330 & 95 & 178 & 501 & 1100 & 1120 & 323 & 540 & 95 & 252 & 1120 & 260 & 347 \\
\hline \multirow{2}{*}{2017} & Jan & 11 & 30 & 100 & 100 & 50 & 50 & 50 & 21 & 200 & 50 & 18 & 250 & 50 & 23 \\
& Feb & 30 & 30 & 60 & 0 & 20 & 150 & 20 & 40 & 10 & 0 & 10 & 60 & 20 & 20 \\
\hline
\end{tabular}

\section{Plankton abundance}

The temporal changes in the phytoplankton and zooplankton abundance values as number per $\mathrm{ml}(\# / \mathrm{ml})$ at the surface layer of the water and at the depth of $-8 \mathrm{~m}$ from the surface in Fethiye Inner bay are shown in Tables 11-14 according to the monthly measurements between March 2016 and February 2017.

Table 11. Temporal change of surface layer phytoplankton abundance (number per ml) at all measurement points

\begin{tabular}{l|c|c|c|c|c|c|c|c|c|c|c|c}
\hline & \multicolumn{10}{|c}{ 2016 } \\
\cline { 2 - 31 } & Mar & Apr & May & Jun & Jul & Aug & Sep & Oct & Nov & Dec & Jan & Feb \\
\hline F01 & 55833 & 11641 & 221839 & 38089 & 8299 & 6963 & 2820 & 5368 & 16287 & 45965 & 81752 & 27166 \\
F02 & 46527 & 9086 & 219607 & 76055 & 10443 & 8091 & 13261 & 31080 & 61605 & 46987 & 31857 & 45398 \\
F03 & 32843 & 7179 & 101325 & 89226 & 5729 & 6921 & 11706 & 7582 & 18469 & 34742 & 55280 & 70518 \\
F04 & 112444 & 20161 & 69361 & 315769 & 8741 & 4047 & 11088 & 17608 & 54267 & 70721 & 93718 & 63724 \\
F05 & 8031 & 14671 & 76132 & 39142 & 16929 & 10448 & 13725 & 11834 & 84207 & 54321 & 19369 & 81138 \\
F06 & 8934 & 16641 & 114803 & 88872 & 7882 & 6966 & 9317 & 21008 & 29176 & 62391 & 99364 & 91007 \\
F07 & 86218 & 18043 & 293864 & 51258 & 18763 & 5168 & 7362 & 7881 & 24748 & 25098 & 25754 & 35920 \\
F08 & 70297 & 17760 & 67343 & 268413 & 9602 & 4993 & 8827 & 27911 & 23648 & 61238 & 109721 & 28246 \\
F09 & 55096 & 7815 & 81279 & 34553 & 8247 & 7168 & 7769 & 38407 & 18604 & 57432 & 94822 & 43181 \\
F10 & 115702 & 16923 & 109821 & 87645 & 6378 & 6882 & 5862 & 12567 & 28379 & 51867 & 79752 & 38131 \\
F11 & 123704 & 10123 & 387105 & 99421 & 7122 & 10963 & 8487 & 28095 & 18737 & 19746 & 20281 & 48803 \\
F12 & 117518 & 10964 & 123619 & 156963 & 11967 & 4569 & 3768 & 27960 & 34183 & 30545 & 26635 & 25279 \\
F13 & 93821 & 15567 & 125742 & 77363 & 8043 & 5802 & 6668 & 33986 & 21864 & 25143 & 29183 & 21149 \\
F14 & 97404 & 7439 & 121095 & 153750 & 4861 & 4089 & 3347 & 4158 & 31268 & 33613 & 37006 & 20869 \\
\hline
\end{tabular}


Table 12. Temporal change of phytoplankton abundance (number per $\mathrm{ml}$ ) at $-8 \mathrm{~m}$ from the surface at all measurement points

\begin{tabular}{|c|c|c|c|c|c|c|c|c|c|c|c|c|}
\hline & \multicolumn{10}{|c|}{2016} & \multicolumn{2}{|c|}{2017} \\
\hline & Mar & Apr & May & Jun & Jul & Aug & Sep & Oct & Nov & Dec & Jan & Feb \\
\hline F01 & 71508 & 4729 & 80751 & 81796 & 5567 & 6043 & 3101 & 6287 & 40233 & 30245 & 20917 & 20133 \\
\hline F02 & 135865 & 9361 & 89611 & 52609 & 10439 & 8922 & 5327 & 16933 & 30173 & 27158 & 25363 & 23704 \\
\hline F03 & 142303 & 13684 & 246129 & 59803 & 8954 & 5963 & 7669 & 9611 & 8386 & 27149 & 46375 & 57352 \\
\hline F04 & 153108 & 31528 & 258198 & 172448 & 8086 & 3247 & 15179 & 9843 & 91279 & 86954 & 83106 & 87611 \\
\hline F05 & 165708 & 32642 & 117305 & 181249 & 11097 & 6019 & 9043 & 18052 & 38719 & 35732 & 34118 & 58792 \\
\hline F06 & 131038 & 11569 & 204311 & 112679 & 7083 & 8687 & 4783 & 28155 & 49811 & 44498 & 40247 & 76619 \\
\hline F07 & 34917 & 14048 & 121374 & 100826 & 15929 & 9281 & 7463 & 11743 & 23823 & 50139 & 82415 & 82193 \\
\hline F08 & 64923 & 13926 & 205103 & 81339 & 8051 & 7246 & 3569 & 7027 & 19403 & 45436 & 77369 & 47351 \\
\hline F09 & 92309 & 13466 & 71233 & 61287 & 16122 & 12844 & 3241 & 38406 & 44611 & 41213 & 38261 & 23769 \\
\hline F10 & 104627 & 14079 & 37581 & 270811 & 23901 & 12847 & 7746 & 5827 & 15332 & 24157 & 32669 & 18351 \\
\hline F11 & 119062 & 14602 & 73427 & 80643 & 8125 & 5521 & 6781 & 4427 & 14482 & 25941 & 40137 & 61837 \\
\hline F12 & 71508 & 4729 & 80751 & 81796 & 5567 & 6043 & 3101 & 6287 & 40233 & 30245 & 20917 & 20133 \\
\hline F13 & 135865 & 9361 & 89611 & 52609 & 10439 & 8922 & 5327 & 16933 & 30173 & 27158 & 25363 & 23704 \\
\hline F14 & 142303 & 13684 & 246129 & 59803 & 8954 & 5963 & 7669 & 9611 & 8386 & 27149 & 46375 & 57352 \\
\hline
\end{tabular}

Table 13. Temporal change of surface layer zooplankton abundance (number per $\mathrm{ml}$ ) at all measurement points

\begin{tabular}{|c|c|c|c|c|c|c|c|c|c|c|c|c|}
\hline & \multicolumn{10}{|c|}{2016} & \multicolumn{2}{|c|}{2017} \\
\hline & Mar & Apr & May & Jun & Jul & Aug & Sep & Oct & Nov & Dec & Jan & Feb \\
\hline F01 & 113 & 327 & 194 & 194 & 457 & 1308 & 301 & 171 & 73 & 84 & 93 & 201 \\
\hline F02 & 98 & 244 & 143 & 146 & 568 & 749 & 458 & 396 & 44 & 75 & 117 & 184 \\
\hline F03 & 85 & 138 & 179 & 337 & 640 & 725 & 745 & 179 & 88 & 98 & 109 & 189 \\
\hline F04 & 76 & 290 & 143 & 284 & 498 & 378 & 201 & 85 & 83 & 89 & 93 & 218 \\
\hline F05 & 101 & 402 & 163 & 225 & 884 & 540 & 626 & 208 & 62 & 98 & 143 & 139 \\
\hline F06 & 99 & 347 & 129 & 211 & 766 & 1211 & 436 & 288 & 93 & 120 & 149 & 129 \\
\hline F07 & 103 & 325 & 165 & 218 & 726 & 2684 & 377 & 201 & 58 & 89 & 123 & 152 \\
\hline F08 & 108 & 284 & 346 & 127 & 523 & 1812 & 781 & 379 & 137 & 142 & 158 & 121 \\
\hline F09 & 197 & 315 & 303 & 78 & 735 & 1359 & 801 & 601 & 147 & 125 & 102 & 117 \\
\hline F10 & 176 & 344 & 276 & 126 & 342 & 832 & 409 & 248 & 81 & 89 & 95 & 217 \\
\hline F11 & 133 & 322 & 101 & 66 & 504 & 761 & 609 & 463 & 99 & 118 & 138 & 189 \\
\hline F12 & 210 & 205 & 165 & 261 & 542 & 747 & 222 & 284 & 105 & 123 & 147 & 163 \\
\hline F13 & 218 & 228 & 663 & 461 & 478 & 1244 & 377 & 492 & 150 & 120 & 86 & 153 \\
\hline F14 & 298 & 456 & 104 & 237 & 264 & 564 & 323 & 163 & 115 & 98 & 81 & 161 \\
\hline
\end{tabular}

Samples from F01 and F02 were dominated by Copepod and copepod nauplii individuals during March 2016. A few numbers of Cladocerans were also observed from the same sample. The dominance of Copepod and copepod nauplii groups were also observed between April and August 2016. Diatoms were the abundant phytoplankton group for the same period. While filamentous and green algae were dominated the April sample for F01 and F02, the system was shifted to filamentous 
algae dominance during May 2016. However, diatoms were the most abundant group in the August sample.

Table 14. Temporal change of zooplankton abundance (number per $\mathrm{ml}$ ) at $-8 \mathrm{~m}$ from the surface at all measurement points

\begin{tabular}{c|c|c|c|c|c|c|c|c|c|c|c|c}
\hline & \multicolumn{10}{|c|}{ 2016 } \\
\cline { 2 - 12 } & Mar & Apr & May & Jun & Jul & Aug & Sep & Oct & Nov & Dec & Jan & Feb \\
\hline F01 & 178 & 347 & 92 & 213 & 544 & 642 & 299 & 198 & 127 & 132 & 120 & 114 \\
F02 & 162 & 298 & 179 & 145 & 551 & 901 & 468 & 164 & 114 & 105 & 128 & 145 \\
F03 & 106 & 209 & 126 & 266 & 566 & 477 & 369 & 189 & 97 & 61 & 136 & 109 \\
F04 & 89 & 372 & 118 & 249 & 431 & 359 & 371 & 156 & 104 & 71 & 148 & 150 \\
F05 & 76 & 375 & 376 & 115 & 610 & 699 & 384 & 79 & 137 & 124 & 152 & 158 \\
F06 & 68 & 417 & 106 & 185 & 969 & 2548 & 627 & 315 & 147 & 129 & 172 & 163 \\
F07 & 43 & 283 & 141 & 37 & 1059 & 1904 & 1104 & 503 & 114 & 101 & 129 & 194 \\
F08 & 46 & 399 & 90 & 259 & 472 & 745 & 209 & 237 & 152 & 165 & 144 & 195 \\
F09 & 57 & 361 & 225 & 258 & 583 & 1026 & 265 & 415 & 221 & 279 & 161 & 134 \\
F10 & 149 & 403 & 153 & 159 & 549 & 1014 & 463 & 317 & 92 & 77 & 109 & 109 \\
F11 & 339 & 395 & 136 & 342 & 439 & 638 & 456 & 207 & 98 & 81 & 113 & 187 \\
F12 & 178 & 347 & 92 & 213 & 544 & 642 & 299 & 198 & 127 & 132 & 120 & 114 \\
F13 & 162 & 298 & 179 & 145 & 551 & 901 & 468 & 164 & 114 & 105 & 128 & 145 \\
F14 & 106 & 209 & 126 & 266 & 566 & 477 & 369 & 189 & 97 & 61 & 136 & 109 \\
\hline
\end{tabular}

Samples from stations F03 and F04 were Copepod and copepod nauplii dominated during March 2016. Moreover, few Cladoceran individuals were spotted at samples from $4 \mathrm{~m}$ depth. Copepod and copepod nauplii were both the abundant groups at the same stations between April and August. Phytoplankton samples for the same stations were dominated with diatoms between March and August. Therefore, filamentous and green algae domination was observed during April and May 2016. While Copepod nauplii and Rotifera groups were dominant at F05 during March, Copepod, Copepod nauplii, and Cladocera groups were observed in April from the same spot. Moreover, Copepod and copepod nauplii abundance was observed between May and September. Diatoms were the dominant phytoplankton group in March for F05. Both filamentous algae and diatom were the observed during April as well. However, the system was shifted to filamentous algae dominance during May. Diatoms were the dominant group at August sampling.

Rotifer and Copepod nauplii were dominant at F06 during March sampling. However, Cladocera, Copepod and Copepod nauplii were found to be the dominant groups in April (2016). Afterward, the abundance of Copepod and Copepod nauplii groups were reached to their highest number from May to the end of August. Diatoms were the dominant phytoplankton group in March among all phytoplankton. Both filamentous and green algae were the most dominant groups together with diatoms in April 2016 samples. While the system was shifted to filamentous algae dominance at May, diatom abundance was observed in August samples.

Copepod and Copepod nauplii group were dominant at F07, F08 and F09 from April to the end of August. Cladocera individuals were also observed at F07 and F09 during the investigation of $8 \mathrm{~m}$ samples in April. Filamentous algae dominance was observed 
between April and May for both stations, and a few individuals of green algae and diatoms were also observed in the same samples. Followingly, diatoms dominated the system during August. The abundant groups were Copepod and Copepod nauplii for F10, F11, F12 and F13 from April until the end of August. Additionally, Cladocera individuals were observed at F11 during April.

Diatoms, filamentous and green algae were found to be the dominant groups for the same stations in April. After that the system was first shifted to filamentous algae dominance during May, then diatom dominance was observed during August. Copepod and Copepod nauplii groups were dominant at F14 between March and August. Additionally, Cladocera individuals were observed in March and April samples. While the diatoms were dominant in March, the system was shifted to diatom, filamentous and green algae dominance in April. Filamentous algae abundance was observed in May, and diatom dominance was found during August.

Copepod and Copepod nauplii were the dominant zooplankton group at F02, F05, F06, F07, F08, F09, F10, F12, F13 and F14 during June. Moreover, some Cladoceran individuals were observed at F01 and F03. Copepod nauplii were the only zooplankton group that was observed at F11. If we summarize phytoplankton distribution, filamentous algae dominance was observed for all stations.

Copepod and Copepod nauplii were dominant zooplankton groups at F01 and F02 during September 2016 sampling. Additionally, Appendicularia individuals were observed in October at both stations for the same period. Copepod and Copepod nauplii were dominant zooplankton groups together with Cladoceran individuals for November 2016 and January 2017 samples. Copepod and Copepod nauplii were the abundant zooplankton groups as well as in March 2017 sampling. Henceforth, members of Rotifera, Cladocera and Appendicularia were observed in the sample. During the investigation of phytoplankton distribution of the stations, diatom dominance was observed for September and October 2016. Small amounts of diatoms and filamentous algae were dominated the November 2016 sample while January 2017 samples were full of green algae and a few diatom species. Diatom dominance was observed at all samples in March 2017.

Copepod and Copepod nauplii dominance was observed between September and November 2016 for F03 and F04. Additionally, a few Appendicularia class individuals were found in $4 \mathrm{~m}$ samples. The abundant groups were Copepod and Copepod nauplii for F03 and F04, and a small number of Cladocera individuals were found in January 2017 samples. Copepod, Copepod nauplii, Cladocera and Appendicularia individuals were observed in March for both stations as well. The phytoplankton samples of F03 and F04 were dominated by diatoms and a few dinoflagellates during September and November 2016. However, filamentous algae dominance were observed in November 2016 for the same spots. January 2017 samples were abundant with green algae and a few diatoms. Diatom dominance was observed at all samples in March 2017.

Copepod and Copepod nauplii were dominant between September and November 2016 for F05, F06, F07, and F08 together with a few Appendicularia class individuals. On the other hand, Copepod, Copepod nauplii, and Rotifera groups were mostly found in January 2017 samples with a small amount of Cladoceran and Appendicularia individuals. The same phytoplankton distribution pattern was observed for F05, F06, F07, and F08. While Diatoms and dinoflagellates were dominated the system during September and October 2016, filamentous algae abundance was found in November 2016 samples. Green algae were dominant in November 2016, and a few diatom species 
were observed in January 2017. The system was shifted to diatom dominance during March 2017.

Copepod and Copepod nauplii were the dominant zooplankton groups for F09, F10, and F11 between September and November 2016. Also, Cladoceran and Appendicularia individuals were found in samples. Sampling points were dominated by Copepod and Copepod nauplii zooplankton groups during January 2017. However, Rotifera abundance was observed together with a few Cladoceran and Appendicularia individuals for March 2017. Phytoplankton distributions of the points showed the same pattern as F05, F06, F07, and F08.

Copepod and Copepod nauplii were the abundant zooplankton groups for F12, F13, F14, and F15 between September and November 2016. Additionally, Cladoceran and Rotifera individuals were observed in October 2016. Copepod and Copepod nauplii were found to be the dominant zooplankton groups in January 2017. Moreover, few Rotifera and Cladoceran individuals were observed in January 2017. Copepod and Copepod nauplii were the dominant zooplankton group in March 2017 together with a small number of Rotifera, Cladocera, and Appendicularia individuals. Phytoplankton distribution of the same stations showed diatom dominance with a few individuals of dinoflagellate for September and October 2016. Filamentous algae were dominant in November 2016. Green algae have dominated the samples during January 2017, and a few diatom species were found in the sample. Diatom abundance was observed in the system in March 2017 samples.

\section{Dissolved oxygen and biochemical oxygen demand}

Dissolved Oxygen (DO) level is one of the most critical parameters in monitoring water quality and is an essential indicator of water mass's ability to support healthy ecosystems (Manivanan et al., 2013). DO is the amount of oxygen present in molecular form to provide life in seawater. The DO can enter the marine environment, directly through mixing and diffusion, or as a by-product of photosynthesis. Therefore, the level of DO in the water may increase due to strong wind and wave motions and the presence of plants and algae. On the other hand, it decreases by respiration and decay. When the plant population is very intense, oxygen consumption increases. Organisms such as bacteria, phytoplankton, and zooplankton need oxygen and consume dissolved oxygen in large quantities. Degradation of organic matter is the most significant oxygen consumer in the system. In general, a dissolved oxygen level of at least $4 \mathrm{mg} / \mathrm{L}$ is required to support live life. In marine environments, chronic oxygen deficiency occurs when the DO amount is between 2.0 and $6.0 \mathrm{mg} / \mathrm{l}$, and hypoxic conditions (acute oxygen deficiency) threaten livelihood occur when DO is lowered than $2.0 \mathrm{mg} / \mathrm{l}$. When the DO level drops below $0.2 \mathrm{mg} / \mathrm{l}$, anoxic or oxygen-free conditions occur (O'Boyle et al., 2009). As temperature and salinity increase, the oxygen concentration in the seawater decreases.

The 12-month measurements between March 2016 and February 2017 were made at every $2 \mathrm{~m}$ from the surface to the sea bottom. The temporal changes of DO measurements at the water surface and at $-14 \mathrm{~m}$ below the surface are presented in Tables 15 and 16, respectively. The seasonal and annual averages of DO (mg/l) at all measurement points are summarized in Table 17. The measured dissolved oxygen values are in between 3.83 and $9.12 \mathrm{mg} / \mathrm{l}$, and the values are decreasing in the summer when the temperature is the warmest. In summer, mean DO values are below $6 \mathrm{mg} / \mathrm{l}$, 
and chronic oxygen deficiency condition is seen. All of the measurements were higher than $2 \mathrm{mg} / \mathrm{l}$ higher and hypoxic or anoxic condition was not observed.

Table 15. Temporal change of surface dissolved oxygen $(\mathrm{mg} / \mathrm{l})$ at all measurement points

\begin{tabular}{c|c|c|c|c|c|c|c|c|c|c|c|c}
\hline & \multicolumn{10}{|c}{ 2016 } \\
\cline { 2 - 12 } & Mar & Apr & May & Jun & Jul & Aug & Sep & Oct & Nov & Dec & Jan & Feb \\
\hline F01 & 9.12 & 6.47 & 7.95 & 6.2 & 5.58 & 5.6 & 6.08 & 5.91 & 6.78 & 6.78 & 6.78 & 7.52 \\
F02 & 8.96 & 6.76 & 7.46 & 6.47 & 5.52 & 5.29 & 5.77 & 5.97 & 6.94 & 6.51 & 6.23 & 7.26 \\
F03 & 8.97 & 6.93 & 8.01 & 6.14 & 5.01 & 5.34 & 6.79 & 6.13 & 6.79 & 6.32 & 7.51 & 7.56 \\
F04 & 7.77 & 7.57 & 7.26 & 5.97 & 5.56 & 5.27 & 6.35 & 6.01 & 7.96 & 6.81 & 7.28 & 7.35 \\
F05 & 7.96 & 7.66 & 8.18 & 6.42 & 5.32 & 5.96 & 6 & 6.16 & 8.48 & 6.73 & 6.87 & 6.73 \\
F06 & 8.21 & 7.2 & 8.57 & 6.41 & 5.41 & 5.37 & 6.26 & 6.62 & 5.68 & 6.8 & 7.55 & 6.95 \\
F07 & 8.18 & 8.16 & 8.32 & 6.95 & 5.07 & 5.91 & 6.7 & 6.09 & 6.72 & 6.3 & 6.02 & 7.69 \\
F08 & 7.89 & 8.66 & 6.79 & 7.26 & 5.23 & 5.99 & 6.01 & 6.81 & 6.43 & 7.1 & 7.55 & 7.32 \\
F09 & 8.8 & 7.6 & 7.57 & 6.9 & 5.53 & 5.3 & 6.23 & 6.52 & 7.25 & 6.74 & 7.64 & 7.1 \\
F10 & 8.55 & 6.55 & 8.34 & 6.05 & 5.33 & 5.38 & 5.9 & 6.17 & 6.53 & 6.95 & 7.23 & 7.8 \\
F11 & 8.25 & 7.69 & 8.48 & 6.98 & 5.15 & 5.38 & 5.46 & 6.48 & 6.35 & 7.12 & 7.64 & 7.64 \\
F12 & 8.55 & 7.25 & 7.37 & 6.32 & 5.15 & 5.89 & 5.79 & 6.41 & 5.31 & 6.28 & 6.94 & 6.48 \\
F13 & 9.03 & 7.33 & 7.33 & 6.41 & 5.37 & 5.64 & 6.53 & 5.99 & 5.43 & 6.27 & 6.84 & 6.76 \\
F14 & 9.03 & 6.64 & 7.07 & 6.34 & 5.56 & 5.43 & 6.44 & 5.92 & 6.26 & 6.49 & 6.62 & 7.98 \\
\hline
\end{tabular}

Table 16. Temporal change of dissolved oxygen ( $\mathrm{mg} / \mathrm{l})$ at $-14 \mathrm{~m}$ below the surface at all measurement points

\begin{tabular}{c|c|c|c|c|c|c|c|c|c|c|c|c}
\hline & \multicolumn{10}{|c|}{ 2016 } \\
\cline { 2 - 13 } & Mar & Apr & May & Jun & Jul & Aug & Sep & Oct & Nov & Dec & Jan & Feb \\
\hline F01 & 7.57 & 7.46 & 7.09 & 6.72 & 6.06 & 5.39 & 5.99 & 5.85 & 6.24 & 6.08 & 5.98 & 6.31 \\
F02 & 7.15 & 7.29 & 6.89 & 6.89 & 6.06 & 5.28 & 5.71 & 5.66 & 6.23 & 6.08 & 5.98 & 6.25 \\
F03 & 7.07 & 6.95 & 6.95 & 6.75 & 5.3 & 4.65 & 6.08 & 5.8 & 6.33 & 5.97 & 5.74 & 6.33 \\
F04 & 7.04 & 7.26 & 6.86 & 6.41 & 3.83 & 4.89 & 5.93 & 5.81 & 6.36 & 6.24 & 6.17 & 6.32 \\
F05 & 7.11 & 7.19 & 6.95 & 6.65 & 5.35 & 4.88 & 5.86 & 5.77 & 6.25 & 6.16 & 6.1 & 6.1 \\
F07 & 7.01 & 7.26 & 6.91 & 6.75 & 5.55 & 5.63 & 5.99 & 5.82 & 6.22 & 6.02 & 5.9 & 6.37 \\
F09 & 7.51 & 7.22 & 6.79 & 6.42 & 5.73 & 5 & 5.93 & 5.71 & 6.11 & 6.11 & 5.97 & 6.28 \\
F10 & 7.18 & 6.73 & 6.99 & 6.84 & 5.9 & 5.36 & 5.48 & 5.36 & 6.06 & 5.63 & 6 & 6.41 \\
F12 & 7.28 & 7.38 & 7.01 & 6.78 & 6.09 & 4.17 & 5.94 & 5.87 & 6.11 & 5.66 & 5.36 & 5.64 \\
F13 & 7.36 & 7.22 & 7.06 & 6.09 & 4.21 & 5.58 & 5.33 & 5.08 & 5.56 & 5.47 & 5.42 & 5.43 \\
F14 & 8.1 & 7.85 & 7.29 & 7.02 & 6.2 & 5.68 & 5.88 & 5.8 & 6.38 & 6.33 & 6.3 & 6.56 \\
\hline
\end{tabular}

Table 17. Dissolved oxygen $(\mathrm{mg} / \mathrm{l})$ seasonal and annual averages

\begin{tabular}{c|c|c|c|c|c}
\hline & Spring & Summer & Autumn & Winter & Annual \\
\hline Surface & 7.87 & 5.79 & 6.34 & 7.00 & 6.75 \\
$-4 \mathrm{~m}$ & 7.56 & 5.78 & 5.99 & 6.44 & 6.44 \\
$-8 \mathrm{~m}$ & 7.55 & 5.87 & 5.99 & 6.22 & 6.41 \\
$-12 \mathrm{~m}$ & 7.28 & 5.85 & 5.98 & 6.07 & 6.29 \\
$-14 \mathrm{~m}$ & 7.18 & 5.76 & 5.89 & 6.02 & 6.21 \\
\hline
\end{tabular}


Biochemical Oxygen Demand (BOD) is a measure of the amount of oxygen that is consumed by microorganisms to break down organic substances. As the water temperature values increase, the BOD values also increase. When the water temperature rises, photosynthesis rate of plants increases, plants grow faster and die. Decay the dead plants by the bacteria requires oxygen, and as a result, the BOD values rise. For this reason, the BOD values in the summer months are higher than the winter months values. The increase in nitrate and phosphate increases the rate of plant growth and death, and thus the organic pollutant load that will be broken down by bacteria in the marine environment. For this reason, the increase in nitrate and phosphate values is also effective in increasing BOD levels. As the BOD level rises, the dissolved oxygen (DO) values used by bacteria are reduced. In the months of intense rainfall, there is an increase in the mixing of the organic materials found in the soil with the sea water. Generally, in the uncontaminated waters, the BOD level is less than $4 \mathrm{mg} / \mathrm{l}$, while it can reach 8-150 mg/l in the wastewater (Regulation of Surface Water Quality, 2016).

According to the 12-month measurements between March 2016 and February 2017, the temporal changes of the BOD values at the surface of Fethiye Inner Bay are presented in Table 18. All measured BOD values range from 2.3-6.8 mg/l.

Table 18. Temporal change of biological oxygen demand $(\mathrm{mg} / \mathrm{l})$ at the surface layer for all measurement points

\begin{tabular}{|c|c|c|c|c|c|c|c|c|c|c|c|c|}
\hline & \multicolumn{10}{|c|}{2016} & \multicolumn{2}{|c|}{2017} \\
\hline & Mar & Apr & May & Jun & Jul & Aug & Sep & Oct & Nov & Dec & Jan & Feb \\
\hline F01 & 2.41 & 5.03 & 3.66 & 4.92 & 3.98 & 5.26 & 5.51 & 5.45 & 3.89 & 3.64 & 3.42 & 3.58 \\
\hline F02 & 3.21 & 5.48 & 4.52 & 4.74 & 4.16 & 5.40 & 5.20 & 3.76 & 3.55 & 3.66 & 3.93 & 3.53 \\
\hline F03 & 2.32 & 3.09 & 3.43 & 4.82 & 5.34 & 4.97 & 4.54 & 3.86 & 3.69 & 3.76 & 4.13 & 3.43 \\
\hline F04 & 2.70 & 4.90 & 3.21 & 5.04 & 5.37 & 5.43 & 4.79 & 5.87 & 4.37 & 3.43 & 3.82 & 3.75 \\
\hline F05 & 3.03 & 3.15 & 4.06 & 4.82 & 5.24 & 5.03 & 4.59 & 4.08 & 4.52 & 4.36 & 3.99 & 4.24 \\
\hline F06 & 3.20 & 3.53 & 3.71 & 4.96 & 5.35 & 4.98 & 5.13 & 3.92 & 4.57 & 4.00 & 3.89 & 4.36 \\
\hline F07 & 3.11 & 3.26 & 3.18 & 4.54 & 4.97 & 4.71 & 4.46 & 4.10 & 4.63 & 4.13 & 4.32 & 3.64 \\
\hline F08 & 2.65 & 2.50 & 2.85 & 4.60 & 4.55 & 6.22 & 5.16 & 4.36 & 4.65 & 3.40 & 3.25 & 3.43 \\
\hline F09 & 2.40 & 2.82 & 2.72 & 4.36 & 4.54 & 4.85 & 4.16 & 4.16 & 3.94 & 3.81 & 3.77 & 3.20 \\
\hline F10 & 2.43 & 3.21 & 3.43 & 4.55 & 5.31 & 5.09 & 4.77 & 3.64 & 3.40 & 3.71 & 3.42 & 3.10 \\
\hline F11 & 4.39 & 5.98 & 6.85 & 5.46 & 5.60 & 4.96 & 5.52 & 5.13 & 4.85 & 4.80 & 4.75 & 4.57 \\
\hline F12 & 2.92 & 3.43 & 4.91 & 4.00 & 5.52 & 4.60 & 4.63 & 4.80 & 6.72 & 5.97 & 5.18 & 4.53 \\
\hline F13 & 2.94 & 3.10 & 4.37 & 4.13 & 4.82 & 4.64 & 3.47 & 4.08 & 4.53 & 4.25 & 3.87 & 3.42 \\
\hline F14 & 2.37 & 3.28 & 3.47 & 3.36 & 3.53 & 5.12 & 3.37 & 4.10 & 3.40 & 3.01 & 3.31 & 2.81 \\
\hline
\end{tabular}

In this study, a three-dimensional coastal waters hydrodynamic (Balas and Özhan, 2003), wave propagation, transport and water quality (Cebe and Balas, 2016) numerical model HYDROTAM-3D, was used and a water quality monitoring and evaluation database system based on geographical information system (GIS) was established. The database system is available at www.hydrotam $3 \mathrm{~d} . \mathrm{com} / \mathrm{fethiye}$ by username: fb and user password: fb. Coordinated and temporal access is provided to all data. 


\section{Results and discussion}

The monthly variations of water quality parameters were investigated through the site measurements conducted in between March 2016 and February 2017. Once at every month, at selected 14 locations, water samples were collected, and total coliform, fecal coliform, fecal streptococci, Escherichia coli, Pseudomonas aeruginosa, Salmonella detection, phytoplankton and zooplankton abundance analyses were performed in the laboratory. By using the related TSE standards, biochemical oxygen demand (BOD) and dissolved oxygen (DO) levels were determined, and water samples were collected from surface and -8 meters below if possible. The physical parameters measured throughout the water column were water temperature, salinity, $\mathrm{pH}$, and turbidity. Changes in parameters measured between March 2016 and February 2017 were summarized in Table 19.

Table 19. The measured ranges of physical and chemical parameters suitable to water samples in Fethiye Inner Bay

\begin{tabular}{c|c|c|c|c}
\hline $\begin{array}{c}\text { Number of } \\
\text { samples }\end{array}$ & Parameters & Mean & Minimum & Maximum \\
\hline 14 & Water Depth (m) & 16.2 & 4.5 & 46 \\
1164 & Salinity (S, ppt), & 37.5 & 30.4 & 39.4 \\
1164 & Temperature (T, $\left.{ }^{\circ} \mathrm{C}\right)$ & 21.4 & 12.7 & 30.8 \\
1164 & $\mathrm{pH}$ & 8.09 & 7.55 & 8.38 \\
168 & Turbidity (Turb.,ntu) & 2.08 & 0.54 & 4.81 \\
168 & Total coliform (TC, cfu/100 ml) & 298 & 0 & 6090 \\
168 & Fecal coliform (FC, cfu/100 ml) & 131 & 0 & 6090 \\
168 & Fecal streptococci (FS, cfu/100 ml) & 28 & 0 & 800 \\
168 & E. coli $(\mathrm{cfu} / 100 \mathrm{ml})$ & 37 & 0 & 933 \\
168 & P. aeruginosa $(\mathrm{cfu} / 100 \mathrm{ml})$ & 174 & 0 & 3350 \\
168 & Salmonella $(\mathrm{cfu} / 100 \mathrm{ml})$ & 930 & 0 & 18550 \\
1164 & DO $(\mathrm{mg} / \mathrm{l})$ & 6.4 & 3.83 & 9.12 \\
168 & BOD $(\mathrm{mg} / \mathrm{l})$ & 4.2 & 2.3 & 6.8 \\
\hline
\end{tabular}

Pearson correlation matrix and related p-values were carried out on all the data set of water samples to describe the relations between measured parameters. In Table 20, coefficient of correlations ( $r$ ) were listed, and significant correlations at $p<0.05$ were indicated. After examination of several scatter plots, it is decided to refer the correlation as a weak correlation if $0.1<\mathrm{r}<0.3$, a moderate correlation if $0.3<\mathrm{r}<0.5$ and a strong correlation if $0.5<\mathrm{r}<1.0$.

According to the correlation analysis, it is seen that temperature shows a weak positive significant correlation with the salinity $(\mathrm{r}=0.28), \mathrm{pH}(\mathrm{r}=0.15)$ and turbidity $(\mathrm{r}=0.25)$. In line with a moderate positive correlation $(\mathrm{r}=0.3)$, as water temperature increases, zooplankton counts increases as well. $\mathrm{pH}$ values show a weak negative correlation with DO $(\mathrm{r}=-0.17)$ and phytoplankton counts $(\mathrm{r}=-0.15)$ and a weak and moderate positive correlations with turbidity $(\mathrm{r}=0.19)$ and zooplankton counts $(\mathrm{r}=0.32)$ respectively. Zooplankton shows a reduction in numbers at the lower $\mathrm{pH}$ levels. 
Table 20. Correlation (r) matrix between all parameters analyzed in Fethiye Inner Bay coastal waters

\begin{tabular}{|c|c|c|c|c|c|c|c|c|c|c|c|}
\hline & $\mathbf{T}$ & $\mathbf{S}$ & pH & DO & BOD & Turb. & TC & FC & FS & Phyto & Zoo \\
\hline $\mathrm{T}$ & 1.00 & & & & & & & & & & \\
\hline S & $0.28^{*}$ & 1.00 & & & & & & & & & \\
\hline $\mathrm{pH}$ & $0.15^{*}$ & -0.08 & 1.00 & & & & & & & & \\
\hline DO & 0.04 & $-0.15^{*}$ & $-0.17 *$ & 1.00 & & & & & & & \\
\hline BOD & 0.06 & $0.33^{*}$ & 0.14 & $-0.61 *$ & 1.00 & & & & & & \\
\hline Turb. & $0.25^{*}$ & $-0.29 *$ & 0.19* & 0.12 & 0.09 & 1.00 & & & & & \\
\hline $\mathrm{TC}$ & 0.03 & 0.02 & 0.03 & -0.12 & $0.34 *$ & -0.03 & 1.00 & & & & \\
\hline FC & 0.10 & 0.01 & 0.02 & -0.12 & $0.24 *$ & -0.06 & $0.85^{*}$ & 1.00 & & & \\
\hline FS & 0.13 & -0.08 & 0.12 & 0.15 & $0.24^{*}$ & $0.20^{*}$ & $0.17^{*}$ & 0.12 & 1.00 & & \\
\hline Phyto & -0.02 & $-0.27 *$ & $-0.15^{*}$ & $0.43^{*}$ & -0.10 & 0.14 & -0.01 & -0.01 & 0.33* & 1.00 & \\
\hline Zoo & $0.30 *$ & 0.10 & $0.32 *$ & $-0.45^{*}$ & $0.35^{*}$ & 0.08 & -0.02 & 0.07 & $-0.13^{*}$ & $-0.30 *$ & 1.00 \\
\hline
\end{tabular}

*significant at $\mathrm{p}<0.05$

As the salinity of coastal waters decreases in rainy seasons, DO $(r=-0.15)$ and phytoplankton counts $(r=-0.27)$ increase and BOD decreases $(r=0.33)$. The measured DO decreases in the summer, as the water temperature increases. In $32 \%$ of the measurements, DO values are below $6 \mathrm{mg} / \mathrm{l}$, and chronic oxygen deficiency condition is seen. DO and BOD values show a strong inverse relation $(\mathrm{r}=-0.61)$ as shown in Figure 5. DO values reach the highest values in the spring, while BOD values are the lowest. It is seen that, as phytoplankton counts $(\mathrm{r}=0.43)$ increase and zooplankton counts $(r=-0.45)$ decrease, DO increases in coastal waters of Fethiye Inner Bay. Whereas zooplankton counts show a positive moderate correlation with BOD $(r=0.35)$.

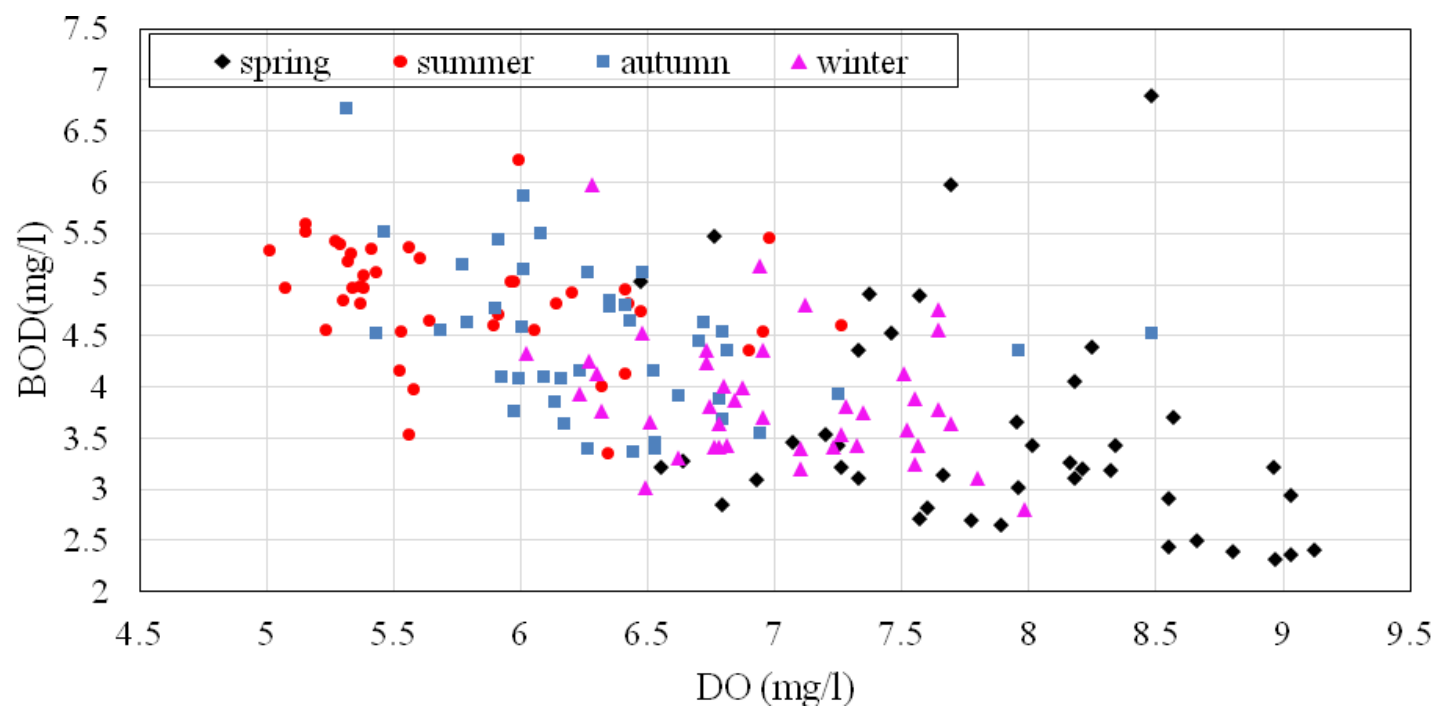

Figure 5. Seasonal change of dissolved oxygen and biological oxygen demand

BOD tends to increase in summer and autumn. This is due to the increase in microorganisms that requires dissolved oxygen to oxidize organic matter. BOD values 
are higher than $4 \mathrm{mg} / \mathrm{L}$ in $55 \%$ of measured samples. It is seen that BOD values have a positive relation with TC $(r=0.34), F C(r=0.24)$ and FS $(r=0.24)$. BOD increases as the concentration values of organic pollutants increase. As an example of this positive relation, timewise changes in BOD, total coliform, fecal coliform and fecal streptococci values at selected measuring points F06 and F12 are presented in Figure 6.

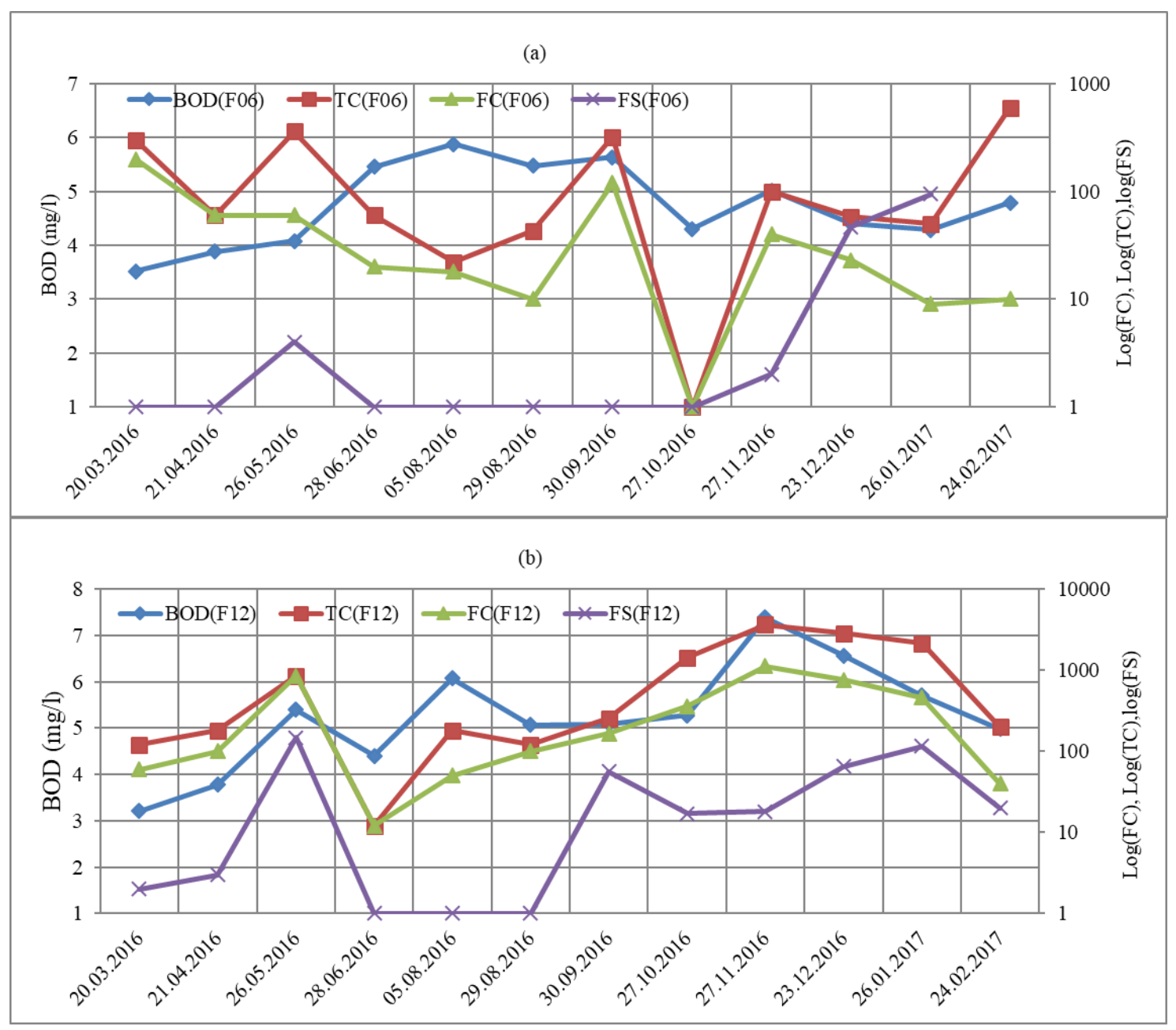

Figure 6. Temporal changes in BOD, total coliform, fecal coliform and fecal streptococci values a) at point F06 b) at point F12

It is seen that as TC amount increases, $\mathrm{FC}(\mathrm{r}=0.85)$ strongly increases and also FS $(\mathrm{r}=0.17)$ shows an increase. In $91.7 \%, 85.7 \%$ and $66.1 \%$ of the samples TC, FC and FS were recorded respectively. In $15.5 \%, 21.4 \%$ and $7.7 \%$ of them were above the TC, FC and FS guide standards respectively. In $38.1 \%$ of the samples $E$. coli was recorded, and $3.6 \%$ and $1.8 \%$ were above the guide standard and the mandatory standard, respectively. It is seen that, FS amount has positive moderate correlation with phytoplankton count $(\mathrm{r}=0.33)$.

In this study, "Spring Bloom" were observed between May and July which corresponds with the highest level phytoplankton abundance in the sampling points and the results are in line with Sverdrup's (1953) study (Colebrook, 1982; Martinez et al., 2011). During the "Spring Bloom", the amount of phytoplankton in aquatic 
environments increase significantly due to less stratification, more stable dispersion of temperature and higher availability of surface nutrients.

After the spring bloom season, there was a decrease in phytoplankton and increase in zooplankton in all samples. Measurements show that there is an inverse correlation between zooplankton and phytoplankton counts $(\mathrm{r}=-0.3)$. Zooplankton numbers were reached to their maximum between August and September, then started to decrease in October. Moreover, a few phytoplankton peaks were also observed in the end of the fall bloom. This pattern corresponded with an event called "Fall Bloom". According to literature, the stratified water column started to mix due to an increase in the atmospheric events that cause an increase in nutrient levels as well in the aquatic ecosystem which results with a bloom in phytoplankton levels for a short period (Sverdrup, 1953). In this study, fall bloom was spotted starting from October, and it lasted for three months.

According to the results of the study performed, the number of total coliform bacteria had a significant increase during May and September. All measured microbiological parameters frequently increase in spring and winter, often exceeding guide standards. In a study by Kim et al. (2000), it was shown that increase in bacterial populations tended to be seasonal, which was in line with results of this study. The observations in the current study showed that zooplankton samples were mostly dominated by copepods which had a low grazing control of bacteria. Correspondingly, it is thought that the bacterial growth is not controlled by zooplankton in this study.

In conclusion, land-based pollutants transported with increasing surface runoff are thought to cause an increase in microorganism concentrations. Swimming in Çalış Beach coastal waters (F12 and F13) might be dangerous for human health. Seasonal averages and high BOD values indicate that the Fethiye Inner Bay is under considerable threat of continuous pollutant loadings. Measurements all indicate that immediate measures should be taken to reduce the land-based pollution causing degradation of coastal water quality in Fethiye Inner Bay.

Acknowledgements. This study was carried out with the support given by the Scientific and Technological Research Council of Turkey (TUBITAK) under the scope of the Project (No: 115Y468) entitled as 'Monitoring and evaluations of water quality parameters in coastal waters'. Authors would like to thank employees of DLTM Software Technologies Limited Company due to their support for field measurements.

\section{REFERENCES}

[1] Altuğ, G. (2012): The Occurrence of Salmonella in Various Marine Environments in Turkey. - In: Barakat, S. M. M. (ed.) Salmonella - A Dangerous Foodborne Pathogen. InTech, Rijeka, pp. 73-90.

[2] APHA (1995): Standard Methods for the Examination of Water and Wastewater. 19th Ed. - American Public Health Association, Washington, DC.

[3] Balas, L., Özhan, E. (2003): A baroclinic three dimensional numerical model applied to coastal lagoons. - Lecture Notes in Computer Science 2658: 205-212. DOI: 10.1007/3540-44862-4_23.

[4] Barcina, I., Gonzalez, J. M., Iriberri, J., Egea, L. (1991): Role of protozoa in the regulation of enteric bacteria populations in seawater. - Marine Microbial Food Webs 5(2). 179-187. 
[5] Blaustein, R. A., Pachepsky, Y., Hill, R. L., Shelton, D. R., Whelan, G. (2013): Escherichia coli survival in waters: Temperature dependence. - Water Research 47(2): 569-578. DOI: https://doi. org/10.1016/j.watres.2012.10.027.

[6] Carter, J. T., Rice, E. W., Buchberger, S. G., Lee, Y. (2000): Relationships between levels of heterotrophic bacteria and water quality parameters in a drinking water distribution system. - Water Research 34(5): 1495-1502. DOI: 10.1016/S00431354(99)00310-3.

[7] Cebe, K. (2016): Water Quality Modelling in Coastal Waters. - PhD Thesis. Gazi University, Graduate School of Natural and Applied Sciences, Civil Engineering Program, Ankara.

[8] Cebe, K., Balas, L. (2016): Water quality modelling in Kaş Bay. - Applied Mathematical Modelling 40(3). 1887-1913. DOI: 10.1016/j.apm.2015.09.037.

[9] Centers for Diseases Control and Prevention (CDC) (2014): The Model Aquatic Health Code. Atlanta, GA. - https://www.cdc.gov/mahc/.

[10] Colebrook, J. M. (1982): Continuous plankton records: seasonal variations in the distribution and abundance of plankton in the North Atlantic Ocean and the North Sea. Journal of Plankton Research 4: 435-462. DOI: 10.1093/plankt/4.3.435.

[11] Craig, D. L., Fallowfield, H. F., Cromar, N. J. (2004): Use of microcosms to determine persistence of Escherichia coli in recreational coastal water and sediment and validation with in situ measurements. - Journal of Applied Microbiology 96(5): 922-930. DOI: 10.1111/j.1365-2672.2004.02243.x.

[12] Directive 2000/60/EC of the European Parliament and of the Council Establishing a Framework for Community Action in the Field of Water Policy. - OJ L327.

[13] Directive 2006/7/EC of the European Parliament and of the Council of 15 February 2006 Concerning the Management of Bathing Water Quality and Repealing. - Directive 76/160/EEC.

[14] Donovan, E., Unice, K., Roberts, J. D., Harris, M., Finley, B. (2008): Risk of gastrointestinal disease associated with exposure to pathogens in the water of the lower Passaic River. - Applied and Environmental Microbiology 74(4): 994-1003. DOI: 10.1128/AEM.00601-07.

[15] Feng, P., Weagant, S., Grant, M., Burkhardt, W., Shellfish, M., Water, B. B. (2012): Enumeration of Escherichia Coli and the Coliform Bacteria. - In: Food and Drug Administration (FDA) (ed.) Bacteriological Analytical Manual Online. 8th Ed., Silver Spring,

Berlin. https://www.fda.gov/Food/FoodScienceResearch/LaboratoryMethods/ucm2006949.htm.

[16] Gao, G., Falconer, R. A., Lin, B. (2015): Modelling the fate and transport of faecal bacteria in estuarine and coastal waters. - Marine Pollution Bulletin 100(1): 162-168. DOI: https://doi.org/10.1016/j.marpolbul.2015.09.011.

[17] Griffin, D. W., Donaldson, K. A., Paul, J. H., Rose., J. B. (2003): Pathogenic human viruses in coastal waters. - Clinical Microbiology Reviews 16(1): 129-143. DOI: 10.1128/CMR.16.1.129-143.2003.

[18] Guida, M., Di Onofrio, V., Gallè, F., Gesuele, R., Valeriani, F., Liguori, R., ... Liguori, G. (2016): Pseudomonas aeruginosa in swimming pool water: evidences and perspectives for a new control strategy. - International Journal of Environmental Research and Public Health 13(9): 919. DOI: 10.3390/ijerph13090919.

[19] Harris, R. P., Wiebe, P. H., Lenz, J., Skjoldal, H. R., Huntley, M. (2000): ICES Zooplankton Methodology Manual. - Academic Press, London.

[20] Karbasdehi, V. N., Dobaradaran, S., Nabipour, I., Ostovar, A., Arfaeinia, H., Vazirizadeh, A., ... Khalifei, F. (2017): Indicator bacteria community in seawater and coastal sediment: the Persian Gulf as a case. - Journal of Environmental Health Science and Engineering 15(1): 6. DOI: 10.1186/s40201-017-0266-2. 
[21] Kim, H.-W., Hwang, S.-J., Joo, G.-J. (2000): Zooplankton grazing on bacteria and phytoplankton in a regulated large river (Nakdong River. Korea). - Journal of Plankton Research 22(8): 1559-1577. DOI: 10.1093/plankt/22.8.1559.

[22] Kimata, N., Nishino, T. F., Fau, S. S., Kogure, K. (2004): Pseudomonas aeruginosa isolated from marine environments in Tokyo Bay. - Microbial Ecology 47(1): 41-47. DOI: 10.1007/s00248-003-1032-9.

[23] Liyanage, C. P., Yamada, K. (2017): Impact of population growth on the water quality of natural water bodies. - Sustainability 9: 1405. DOI: 10.3390/su9081405.

[24] Manivanan, R. P., Sinha, J. S., Kanetkar, C. N. (2013): Development and application of dissolved oxygen (DO) and biological oxygen demand (BOD) model for Panshet and Ujjani Reservoirs, Maharashtra, India. - Lakes and Reservoirs: Research and Management 18(3): 217-226. DOI: 10.1111/lre.12033.

[25] Martinez, E., Antoine, D., D’Ortenzio, F., de Boyer Montégut, C. (2011): Phytoplankton spring and fall blooms in the North Atlantic in the 1980s and 2000s. - Journal of Geophysical Research: Oceans 116(C11). DOI: 10.1029/2010JC006836.

[26] Mena, K. D., Gerba, C. P. (2009): Risk assessment of Pseudomonas aeruginosa in water. - Reviews of Environmental Contamination and Toxicology 201: 71-115. DOI: 10.1007/978-1-4419-0032-6_3.

[27] O'Boyle, S., McDermott, G. F., Wilkes, R. (2009): Dissolved oxygen levels in estuarine and coastal waters around Ireland. - Marine Pollution Bulletin 58(11). DOI: 1657-1663. 10.1016/j.marpolbul.2009.07.002.

[28] Regulation for the Quality of Bathing Water (2006): Rebulic of Turkey Ministry of Environment and Forestry. - Official Gazette date: January 9, 2006. No: 26048. http://www.resmigazete.gov.tr/eskiler/2006/01/20060109-2.htm.

[29] Regulation for the Surface Water Quality (2016): Republic of Turkey Ministry of Forest and Water Management. - Official Gazette date: August 10, 2016. No: 2979. http://www.resmigazete.gov.tr/eskiler/2016/08/20160810-9.htm.

[30] Regulation for the Water Pollution Control (2004): Republic of Turkey Ministry of Environment and Forestry. - Official Gazette date: December 31, 2004. No: 25687. http://www.mevzuat.gov.tr/Metin.Aspx?MevzuatKod=7.5.7221\&sourceXmlSearch=\&M evzuatIliski $=0$.

[31] Rozen, Y., Belkin, S. (2001): Survival of enteric bacteria in seawater. - FEMS Microbiology Reviews 25(5): 513-529. DOI: 10.1111/j.1574-6976.2001.tb00589.x.

[32] Sinton, L. W., Donnison, A. M., Hastie, C. M. (1993): Faecal streptococci as faecal pollution indicators: A review. Part II: Sanitary significance, survival and use. - New Zealand Journal of Marine and Freshwater Research 27(1): 117-137. DOI: 10.1080/00288330.1993.9516550.

[33] Sverdrup, H. U. (1953): On conditions for the vernal blooming of phytoplankton. - ICES Journal of Marine Science 18(3): 287-295. DOI: 10.1093/icesjms/18.3.287.

[34] Troussellier, M., Bonnefont, J.-L., Courties, C., Derrien, A., Dupray, E., Gauthier, M., ... Pommepuy, M. (1998): Responses of enteric bacteria to environmental stresses in seawater. - Oceanologica Acta 21(6): 965-981. DOI: https://doi.org/10.1016/S03991784(99)80019-X.

[35] TS EN ISO 7899-2 (2000): Water quality - Detection and enumeration of intestinal enterococci - Part 2: Membrane filtration method. - Turkish Standards Institution, Ankara, Turkey.

[36] TS EN ISO 10707 (2005): Water quality - Evaluation in an Aqueous Medium of the "Ultimate" Aerobic Biodegradability of Organic Compounds - Method by Analysis of Biochemical Oxygen Demand (Closed Bottle Test). - Turkish Standards Institution, Ankara, Turkey.

[37] TS EN ISO 16266 (2009): Water Quality - Detection and Enumeration of Pseudomonas Aeruginosa - Method by Membrane Filtration. - Turkish Standards Institution, Ankara, Turkey. 
[38] TS EN ISO 5814 (2012): Water Quality-Determination of Dissolved Oxygen Electrochemical Probe Method. - Turkish Standards Institution, Ankara, Turkey.

[39] TS EN ISO 9308-1 (2014): Water Quality - Enumeration of Escherichia Coli and Coliform Bacteria - Part 1: Membrane Filtration Method for Waters with Low Bacterial Background Flora. - Turkish Standards Institution, Ankara, Turkey.

[40] United States Environmental Protection Agency (EPA) (2002): National Water Quality Inventory: Report to Congress. - 2002 Reporting Cycle, Washington DC. https://www.epa.gov/sites/production/files/201509/documents/2007_10_15_305b_2002report_report2002305b.pdf.

[41] Rees, G., Pond, K., Kay, D., Bartram J., Santo Domingo, J. (2010): Safe Management of Shellfish and Harvest Waters: Minimizing Health Risks from Sewage-Contaminated Shellfish. - World Health Organization, Geneva and IWA, London.

[42] Y1lmaz, N., Cebe, K., Y1ldirım, F. P., İnan, A., Balas, L. (2017): The need for the integration of land use planning and water quality modeling in the case of Fethiye Bay. Journal of Polytechnic 20(2): 427-435. DOI: 10.2339/2017.20.2 427-435. 